\title{
ARTICLES
}

\section{Tax Liability for Wage Theft}

\author{
Sachin S. Pandya*
}

\begin{abstract}
This paper shows how, under existing tax law, illegal wage underpayment by an employer (sometimes called "wage theft") may generate employer tax liability for unreported income or disallowed business expense deductions. Given that the tax authority needs information from the underpaid worker to prove such liability, the paper identifies two ways that a worker can transmit that information to a tax authority: becoming a tax informant, or bringing a qui tam action under a state false claims act. Finally, the paper discusses possible influences on the decision of the unpaid worker to inform on the employer to the tax authority, and considers the conditions under which a tax authority is likely to audit an employer based on such information. In so doing, the paper identifies a new approach to combating wage theft and an undiscovered implication of basic income tax law.
\end{abstract}

\footnotetext{
* Associate Professor of Law, University of Connecticut School of Law. For comments on prior drafts, thanks to Stephen Utz, Peter Siegelman, Richard Pomp, Ruth Mason, Diana Leyden, and Francine Lipman.
} 
I. INTRODUCTION

II. TAX LIABILITY

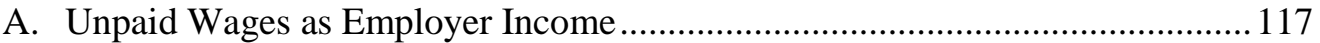

1. The Value of Misappropriated Labor is Employer Income ........................ 117

2. Gross Income Includes Gains Derived From Illegal Activity ...................... 119

3. Illegality and Fair Market Value ........................................................... 120

B. Wage Underpayment and Business Expense Deductions .................................. 123

1. Unpaid Wages as Business Expense Deductions ...................................... 123

2. Wage Payments that Violate Criminal Provisions of Minimum Wage Statutes

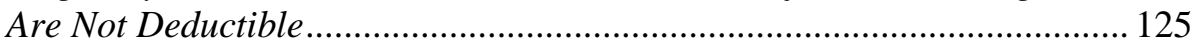

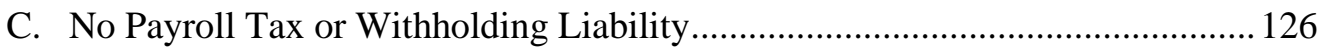

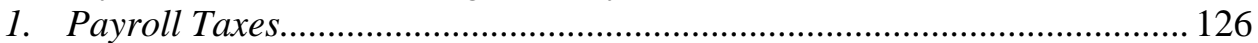

2. Income Tax Withholding ...................................................................... 127

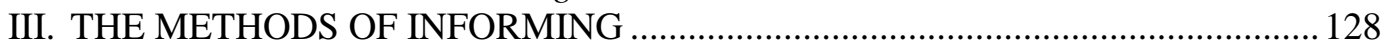

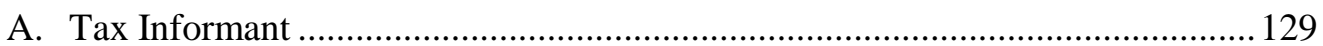

B. Qui Tam Action under State False Claims Act................................................. 131

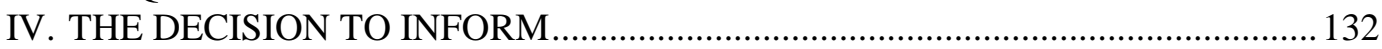

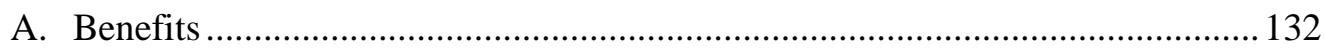

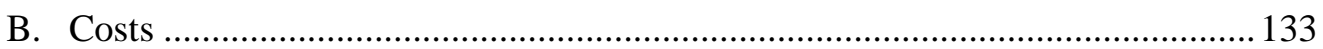

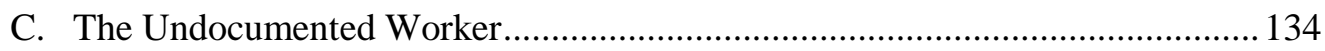

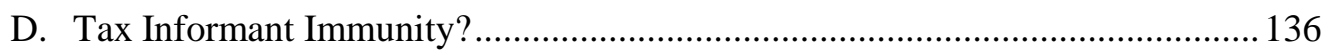

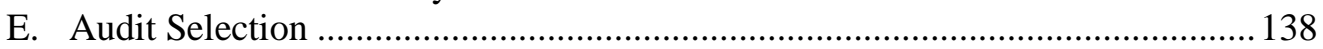

V. COMPLEMENT TO OTHER LAW ENFORCEMENT APPROACHES .............. 140

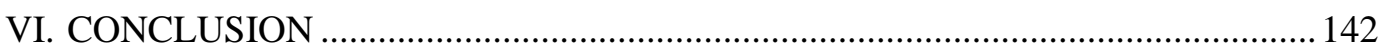

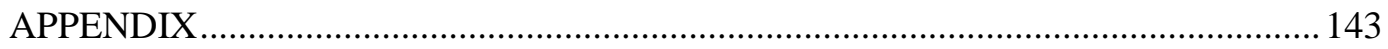




\section{INTRODUCTION}

Employers often pay low-wage workers less than the wages that they must pay by law. This wage underpayment (sometimes called "wage theft") is widespread. ${ }^{1}$ It persists in low-wage sectors, despite the prospect of private civil actions under state contract law and the Fair Labor Standards Act ("FLSA"), civil proceedings by the United States Department of Labor ("USDOL") and by state departments of labor, ${ }^{2}$ and state prosecutions under criminal theft-of-service statutes. ${ }^{3}$ There are many plausible explanations for why such wage theft persists. Some of them include the predominance of small firms; the growth of subcontracting; employer misclassifications of employees as independent contractors to avoid liability under FLSA and under other laws; and the particular prevalence and vulnerability of undocumented workers. ${ }^{4}$

In turn, proposals to combat wage theft roughly fall into two groups. One group of proposals focuses on how existing enforcement institutions, such as USDOL, can best use their limited resources to increase compliance. These include tailoring enforcement strategy to the unique structure of particular industries; encouraging employers to hire third-party private monitors of labor violations ${ }^{5}$; and recruiting unions, workers' centers, and other non-governmental organizations (NGOs) to gather information and, in some cases, monitor workplaces directly. ${ }^{6}$

A second group of proposals focuses on amending existing law to overcome standard problems with private lawsuits by the unpaid workers. One such problem is judgment-proof defendants. Another is firms down the supply chain that pressure their contractors to reduce labor costs below mandated minimums but do not count as the unpaid worker's "employer" under existing law. Possible solutions include holding corporate shareholders jointly and severally liable for unpaid wages owed by the corporation, ${ }^{7}$ as well as imposing unpaid-wages liability on any and all firms down the supply chain that buy or sell the non-complaint employer's goods and services, regardless

\footnotetext{
${ }^{1}$ See, e.g., ANNETte Bernhardt ET AL., BROKEn LAWs, UnProtected WORKERs: Violations of EMPLOYMENT AND LABOR LAWS IN AMERICA'S CITIES (2008).

${ }^{2}$ See, e.g., U.S. Gov't ACCOUNTABILITy OfFice, DePartment Of Labor: Wage and Hour

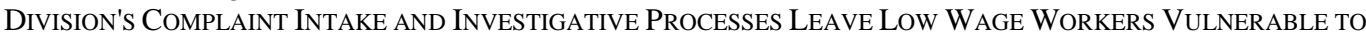
WAGE THEFT (2009).

${ }^{3}$ Rita J. Verga, An Advocate's Toolkit: Using Criminal Theft of Service Laws to Enforce Workers' Right to Be Paid, 8 N.Y. CiTY L. Rev. 283 (2005).

${ }^{4}$ See, e.g., Janice Fine \& Jennifer Gordon, Strengthening Labor Standards Enforcements through Partnerships with Workers' Organizations, 38 POL. \& SoC'Y 552, 554-55 (2010); David Weil, Enforcing Labour Standards in Fissured Workplaces: The US Experience, 22 ECON. \& LABOUR REL. REV. 33, 36-43 (2011).

${ }^{5}$ On different views of the success of this kind of approach to apparel contractors in the Los Angeles area by the U.S. Department of the Labor in the late 1990s, compare JILL ESBENSHADE, MONITORING SweAtshops: Workers, CONSUMERs AND the Global ApPAREl Industry 60-118 (2004) with David Weil, Public Enforcement/Private Monitoring: Evaluating a New Approach to Regulating the Minimum Wage, 58 INDUS. \& LAB. REL. REV. 238 (2005).

${ }^{6}$ Fine \& Gordon, supra note 4, at 558-75.

${ }^{7}$ See N.Y. Bus. CORP. LAW $§ 630$ (a) (2012); MASs. GEN. LAws ch. 156, § 35 (2011). Cf. Eric Tucker, Shareholder and Director Liability for Unpaid Workers' Wages in Canada: From Conditions of Granting Limited Liability to Exceptional Remedy, 26 LAw \& HIST. REV. 57 (2008) (history of such laws in Canada); Kenneth B. Davis, Jr., Shareholder Liability for Claims by Employees, 1984 WIS. L. REV. 741 (criticizing later-repealed Wisconsin statute).
} 
of whether those other firms can be deemed to be the worker's "employer" under the FLSA or other laws. ${ }^{8}$

This paper identifies an unexpected source of existing law for addressing employer wage underpayment: tax law. Part II argues that under existing federal and state tax law, under certain circumstances, employers may face income tax liability for wage underpayment if those employers fail to report the unpaid wages as gross income or take an unallowable business-expense deduction for those unpaid wages.

The rest of the paper then discusses how such tax liability could be enforced. Part III suggests that because unpaid workers have the best evidence of wage underpayment, such tax liability cannot be effectively enforced unless those workers or their agents tell the Internal Revenue Service (IRS) or state tax authorities what they know. To do this, those workers can become tax informants. In a few states, those workers can also pursue qui tam tax fraud actions under the state's false claims act. In Part IV, the paper discusses the conditions under which the unpaid worker might pursue these avenues, and in turn considers when a tax authority is likely to audit an employer based on such an informant's information. Finally, Part V shows how the tax approach identified here complements other legal approaches to combating wage theft.

In so doing, this paper contributes to the research literature in two ways. First, the tax and employment law literatures have rarely covered wage underpayment as a tax liability issue. ${ }^{9}$ To date, no one has identified a basis under existing tax law for treating wage underpayment as generating employer tax liability, let alone discussed how such liability might be enforced. In doing so, this paper bridges the tax and employment law literatures by offering a new legal approach to combating wage theft. This approach is best taken not as a substitute for, but an important complement to, existing legal approaches. Second, the paper advances the theoretical literature on the law enforcement uses of bounties and rewards. That literature has discussed tax informant rewards and qui tam actions ${ }^{10}$ but has not focused on the low-wage or undocumented worker as a tax informant.

${ }^{8}$ E.g., Timothy B. Glynn, Taking the Employer Out of Employment Law? Accountability for Wage and Hour Violations in an Age of Enterprise Disaggregation, 5 EMP. RTS. \& EMP. POL'Y J. 201, 227-28 (2011) (proposing strict liability for wage and hour violations in the production of any goods and services that a firm buys, sells, or distributes, but "only for the portion of the violations attributable to the goods or services it purchases, sells, or distributes"); Hina B. Shah, Broadening Low-Wage Workers' Access to Justice: Guaranteeing Unpaid Wages in Targeted Industries, 28 HOFSTRA LAB. \& EMP. L.J. 9, 35-37, 43-44 (2010) (advocating extension of wage-guarantee provision on garment manufacturers in California Labor Code section 2673.1 to other low-wage sectors and with a private enforcement mechanism); Brishen Rogers, Toward Third-Party Liability for Wage Theft, 31 BERKELEY J. EMP. \& LAB. L. 1, 34-60 (2010) (arguing for liability for downstream buyers of goods and services that fail to exercise due care to prevent wage and hour violations by upstream suppliers).

${ }^{9}$ An exception is Crane, who briefly considered the tax treatment of wage underpayment in a theoretical tax system with a completely closed tax base. Charlotte Crane, Liabilities and the Need to Keep the Income Tax Base Closed, 25 VA. TAx REV. 31, 54 (2005).

${ }^{10}$ Yosef Mealem et al., Whistle-blowers as Deterrents to Tax Evasion, 38 PUB. FIN. REV. 306 (2010); Omri Yadlin, The Conspirator Dilemma: Introducing the "Trojan Horse" Enforcement Strategy, 2 REV. LAW \& ECON. 25 (2006); Ben Depoorter \& Jeff De Mot, Whistle Blowing: An Economic Analysis of the False Claims Act, 14 SuP. CT. ECON. REv. 135 (2006); Robert Cooter \& Nuno Garoupa, The Virtuous Circle of Distrust: A Mechanism to Deter Bribes and Other Cooperative Crimes (University of California, Berkeley Program in Law \& Economics, Working Paper Series, 2000); Gideon Yaniv, Revenge, Tax Informing, and the Optimal Bounty, 3 J. PuB. ECON. THEORY 225 (2001); Marsha J. Ferziger \& Daniel G. Currell, Snitching 


\section{TAX LIABILITY}

This Part presents a legal argument that, under existing federal and state tax law, an employer may incur income tax liability for failing to report gross income derived from not paying wages owed for services rendered, or for claiming paid or unpaid wages as deductible business expenses. This Part also concludes that wage underpayment does not generate employer payroll tax liability or violations of income tax withholding requirements.

\section{A. Unpaid Wages as Employer Income}

An employer that practices wage underpayment faces penalties under tax law that may arise because the employer has failed to report the unpaid wages as gross income. This conclusion derives from two settled readings of $\S 61(\mathrm{a})$ of the Internal Revenue Code, which defines gross income to include, unless otherwise provided, "all income from whatever source derived." First, a taxpayer that benefits from a service has received income. Second, gain derived from an activity is not excluded from gross income simply because that activity is illegal. Moreover, it is also relatively settled that a taxpayer that benefits from a service has received income to the extent of the fair market value of that service, an approach that, as argued here, implies that the amount of income so received cannot be less than the amount of pay to which the worker was entitled under existing laws.

The discussion that follows similarly implicates liability under state tax law. Most states that tax personal or corporate income have incorporated the federal definition of gross income and, accordingly, these readings thereof, into their own tax law by adopting the federal income tax base (variously, federal gross, adjusted gross, net, or taxable income) as at least the starting point for calculating state income tax. ${ }^{11}$

\section{The Value of Misappropriated Labor is Employer Income}

When an employer underpays wages, the employer gains an item of income. This follows in two steps.

First, when an employer underpays wages, the employer gains income by paying less than the cash value of the services performed by the worker. Suppose the employer promised the worker $\$ 100$ in exchange for performing certain services, and that $\$ 100$ is the cash value of those services. If the employer then only paid $\$ 45$ upon completion of those services, then the employer has gained $\$ 55$ in income. The income arrives to the employer in the form of the gain from services equal to the cash value of those services $(\$ 100)$, less the amount actually paid for them $(\$ 45)$. This amount is income even though the gain arrives in the form of services, not cash or property. Section 61(a) covers income "from whatever source." Moreover, Treasury Regulation § 1.61-1(a) provides that " $[\mathrm{g}] \mathrm{ross}$ income includes income realized in any form, whether in money, property, or services. Income may be realized, therefore, in the form of services . . a as well as in cash." 12

Second, for wage underpayment to generate employer income, the employer must not recognize any employer obligation to pay the worker the wages owed but as yet unpaid. If both worker and employer agree that the employer is so obliged, then the

for Dollars: The Economics and Public Policy of Federal Civil Bounty Programs, 1999 U. ILL. L. Rev. 1141 (1999).

\footnotetext{
${ }^{11}$ All St. Tax Guide (RIA) II 221 (2011).
}

12 Treas. Reg. § 1.61-1(a) (1960). 
unpaid wages are not income, but a debt. Proceeds from loans do not count as gross income under federal and state tax law, because both debtor and creditor recognize that the debtor is legally obliged to repay the amount in question, and that liability is treated as offsetting the debtor's gain from the loan proceeds. ${ }^{13}$ Thus, unpaid wages are income to the employer if and when that employer stops recognizing those unpaid wages as a debt to be paid to the worker for services rendered. ${ }^{14}$

Accordingly, when the unpaid wages count as part of employer gross income depends on when the employer stops treating those unpaid wages as a debt. This matters if the employer stops treating the unpaid wages as a debt in a taxable year after the taxable year in which the worker renders services. To illustrate, consider by analogy an employer that attempts to pay wages to a worker and then, after a time, when those wages remain uncollected, decides to stop treating those wages as a debt. For example, in Charleston \& W.C. Ry. Co. v. Burnet (1931), a steam railroad company had "carried" $\$ 441.05$ in uncollected employee wages "on its books to be paid when called for, or when those entitled were located," and the company had taken a deduction for those wages in 1921. ${ }^{15}$ In December 1924, the company made an entry in its books "crediting 'Profit and Loss' with $\$ 441.05$ on account of" those still unpaid wages. The court reasoned: "Though the company intended paying proper claims on the fund if and when sought," since the "effect" of this bookkeeping change made available the $\$ 441.05$ "for general uses," it became "a part of the [company's] gross revenue in 1924 as though paid in that year," and thus "a part of the net on which the tax levied became due." 16 Although the railroad company never actually paid the $\$ 441.05$ before or during 1924, that amount became part of its gross income only in 1924, because, as evinced by the bookkeeping change, only in that year did it stop treating those wages as a liability on its books (a debt). ${ }^{17}$ To be sure, the company may have done so because it doubted that the workers

${ }^{13}$ Joseph M. Dodge, Exploring the Income Tax Treatment of Borrowing and Liabilities, or Why the Accrual Method Should Be Eliminated, 26 VA. TAx REV. 245, 253-55 (2006); Boris I. Bittker \& Barton H. Thompson Jr, Income from the Discharge of Indebtedness: The Progeny of United States v. Kirby Lumber Co., 66 CAL. L. REV. 1159 (1978).

${ }^{14}$ I.R.C. § 61(a)(12) (2006). The argument is not that employer wage underpayment generates employer "[i]ncome from discharge of indebtedness." For that to happen, the unpaid worker (the creditor) has to have taken the additional and unlikely step of forgiving or canceling the employer's debt (the liability for the unpaid wages). Even then, gain from discharge-of-indebtedness is excluded from gross income "to the extent that payment of the liability would have given rise to a deduction." I.R.C. § 108(e)(2) (2006). Wage payments are deductible as business expenses under I.R.C. § 162. See I.R.C. § 162(a)(1) (2006) (allowing as a deduction "a reasonable allowance for salaries or other compensation for personal services actually rendered"). Therefore, any cancellation of an employer's wage debt by the worker would still not result in discharge-of-indebtedness income.

${ }^{15}$ Charleston W. C. Ry. Co. v. Burnet, 50 F.2d 342, 343 (D.C. Cir. 1931).

${ }^{16} \mathrm{Id}$. Then, as now, federal tax law defined a corporation's gross income, absent certain exceptions, to follow the definition of an individual's gross income. I.R.C. § 985(a) (1925-26). That definition included "gains, profits, and income derived from . . . the transaction of business carried on for gain or profit, or gains or profits and income derived from any source whatever." Id. § 954(a).

${ }^{17}$ For other uncollected-wage examples, see Chicago R.I. \& P. Ry. Co. v. Comm'r, 47 F.2d 990, 992 (7th Cir. 1931) (Commissioner properly charged to gross income company checks and vouchers for compensation for services and in payment of loss or damage claims that company charged to profit and loss if not presented for payment within two years from date issued); Beacon Auto Stores, Inc. v. Comm'r, 42 B.T.A. 703, 704-05 (1940) (corporation realized income when it extinguished undrawn salary credits to shareholders by debit to their individual accounts and a corresponding credit to surplus account). Uncollected-wage tax cases like Charleston \& W.C. Ry. Co. may well be far less likely today given the widespread adoption of state escheat statutes, most of which impose a one-year period before uncollected 
would ever collect the unpaid wages, even while still intending to pay those wages if those workers sought to collect. In contrast, in a wage theft scenario, the employer abandons any intent to pay even if the worker later seeks to collect. In either case, however, what matters is that the employer stopped treating the unpaid wages as a debt, not the precise reason why it did so.

\section{2. $\quad$ Gross Income Includes Gains Derived From Illegal Activity}

When an employer underpays wages, the employer gains income for tax law purposes even though such underpayment is illegal under other law. Since United States v. Sullivan (1927), the United States Supreme Court has read the federal tax code's definition of income to include gains derived from illegal activity. ${ }^{18}$ In Sullivan, the taxpayer had been convicted for failing to file a tax return as required by the Revenue Act of 1921. The case turned on whether the Revenue Act of 1921 required the taxpayer to report his income derived from selling intoxicating liquor, an activity that violated the National Prohibition Act. In upholding the conviction, the Court emphasized that while the Revenue Act of 1913 had defined a taxable person's net income to include "the transaction of any lawful business carried on for gain or profit," the word "lawful" did not appear in the successor provision in the Revenue Act of 1921. ${ }^{19}$ In later definitions of income under federal tax law, Congress continued this omission.

Years later, in James $v$. United States (1961), the Court confirmed that embezzled funds count as income by ruling that a union official who had embezzled from his employer union was obliged to report those illegal appropriations as gross income in the year in which they were received. The Court declared: "When a taxpayer acquires earnings, lawfully or unlawfully, without the consensual recognition, express or implied, of an obligation to repay and without restriction as to their disposition," those earnings count as gross income under I.R.C. § 61(a), even though the taxpayer may be later found not to be entitled to it. ${ }^{20}$

In this respect, James simply confirmed that gains from illegal activity fall within the general rule that tax treatment of a gain as proceeds from a debt or as income turns on whether both sides of the transaction recognize any obligation to repay in the taxable year. In James and other embezzlement cases, the illegally obtained money or property has counted as income in the year of receipt, presumably because the embezzler intended to use the acquired money or property for personal use (the embezzlement) at the same time, or in the same year, that he acquired it. Subsequent examples of illegal gross income in lower court opinions include racing tickets stolen by the employee of a betting

wages are deemed abandoned to the state. See 1 David J. Epstein, UnClaimed Property LAw And REPORTING FORMS $§ 5.21$ (2012).

${ }^{18}$ See Boris I. Bittker, Taxing Income From Unlawful Activities, 25 CASE W. RES. L. ReV. 130 (1974); Frank M. Keesling, Illegal Transactions and the Income Tax, 5 UCLA L. REv. 26, 26-33 (1958).

${ }^{19}$ United States v. Sullivan, 274 U.S. 259, 263 (1927). Congress had removed "lawful" from the definition of income in 1916. Revenue Act of 1916, Pub. L. No. 271, § 2(a), 39 Stat. 756, 757. Henry Campbell Black declared it "probable" that Congress had intended the word "lawful" in the Revenue Act of 1913 to "exclude occupations forbidden to all persons, as being immoral or contrary to public policy" out of concern that "taxing them might appear to legalize them." Henry CAMPBEll Black, A Treatise On the LAW OF InCOME TAXation Under Federal AND State LaWs 99 (1913).

${ }^{20}$ James v. United States, 366 U.S. 213, 219 (1961) (Warren, C.J., plurality opinion). 
parlor $^{21}$ and sums received for vessel repair services that were invoiced but not actually performed. $^{22}$

\section{Illegality and Fair Market Value}

Whereas the illegality of wage underpayment does not preclude counting the benefit of services received as gross income to the employer, such illegality can affect how much income an employer gains from wage underpayment, because of the "fair market value" approach to valuation of services.

Since the early twentieth century, federal tax law has determined the cash value of property using the concept of "fair market value," defined for certain federal income tax purposes as "the price at which the property would change hands between a willing buyer and a willing seller, neither being under any compulsion to buy or sell and both having reasonable knowledge of relevant facts." 23

The IRS has often used a "fair market value" concept for determining the cash value of services without any apparent difference in meaning when applied to services instead of property. ${ }^{24}$ For example, since at least 1938, a Treasury regulation has provided that when a person pays for services rendered with property rather than cash, the resulting income to the payee is "the fair market value of the property taken in payment." 25 The same regulation also provides: "If the services are rendered at a stipulated price, such price will be presumed to be the fair market value of the compensation received in the absence of evidence to the contrary." ${ }^{, 6}$ To illustrate this presumption, suppose a taxpayer initially agrees to provide services for $\$ 100$ (the "stipulated price") but thereafter accepts a wood table in lieu of that $\$ 100$ as payment.

${ }^{21}$ Collins v. Comm'r, 3 F.3d 625, 627 (2d Cir. 1993).

${ }^{22}$ McGee v. Comm'r, 519 F.2d 1121, 1123 (5th Cir. 1975).

${ }^{23}$ Treas. Reg. $\S 1.170-1$ (c)(1) (as amended in 1972) (charitable contribution of property); Treas. Reg. § 1.170A-1(c)(2) (as amended in 2008) (same); Treas. Reg. § 1.412(c)(2)-1 (1980) (deferred compensation plan assets); Treas. Reg. § 1.415(c)-1(b)(5) (2007) (contribution of property to defined contribution plan); Treas. Reg. \$ 31.3121(i)-4 (1973) (clothing provided to members of certain religious orders); see also Treas. Reg. $\S \S 1.704-4(a)(3), 1.737-1(b)(2)$ (1995) (similar for property distributed to partnership). A similar definition of "fair market value" of property appears in the federal estate tax, Treas. Reg. § 20.2031-1(b) (as amended in 1965), and the federal gift tax, Treas. Reg. § 25.2512-1 (1992). This definition of "fair market value" precedes its appearance in federal tax law. For early critical commentary on this definition as it appeared in other laws, see JAMEs C. Bonbright, The VAluATION OF Property: A Treatise on the APPRAisal of Property for DifFerent Legal PurPoses 59-61 (1937). On applications and extensions of this definition of "fair market value" for property valuation under federal tax law, see JOHN A. Bogdanski, Federal Tax Valuation II 2.01 (1996 \& Supp. 2011).

${ }^{24}$ See, e.g., Treas. Reg. § 1.74-1(a)(2) (1960) (services provided as a prize); Treas. Reg. $\$ 1.952-$ 1(a)(4) (as amended in 2002) (illegal payment in the form of services by or on behalf of a controlled foreign corporation to government officials); Treas. Reg. § 1.82-1(a)(2) (as amended in 1978) (employer moving of employee's "household goods and personal effects from the employee's old resident to his new residence using the employer's facilities"); Treas. Reg. § 1.170A-1(h)(1)(i)-(ii),(2)(i)(B) (as amended in 2008) (services for which taxpayer makes payment claimed as charitable contribution); Treas. Reg. § 1.199-3(i)(4) (2008) (allocation for domestic production gross receipts attributable to performance of embedded services); Treas. Reg. $§ 1.263(a)-4(d)(8)$ (2004) (services to produce or improve real property); Treas. Reg. § 1.276-1(f)(3) (as amended in 1969) (whether proceeds received by political candidate for services rendered are received in ordinary course of candidate's trade or business); Treas. Reg. § 1.1441-3(e)(1) (as amended in 2012) ("The amount of a payment made in a medium other than U.S. dollars is measured by the fair market value of the property or services provided in lieu of U.S. dollars.").

${ }^{25}$ Treas. Reg. $§ 1.61-2(d)(1)$ (as amended in 2003).

${ }^{26}$ Id. For discussion, see, for example, BogdansKI, supra note 23, I[ 3.07[4]; Robert I. Keller, The Taxation of Barter Transactions, 67 MinN. L. REV. 441, 456-57 (1982). 
Under this regulation, the fair market value of that wood table, and thus the resulting income to the taxpayer, is presumptively $\$ 100$.

In 1957, this regulation was amended to include services as well as property. ${ }^{27}$ Today, that regulation provides that when a person pays for services with other services, the resulting income to the payee is "the fair market value of such other services." ${ }^{28}$ For example, if a housepainter paints a lawyer's house in exchange for the lawyer's personal legal services, the housepainter's gross income must include the "fair market value" of those legal services. ${ }^{29}$ The "stipulated price" presumption remains: If the non-cash compensated services "are rendered at a stipulated price, such price will be presumed to be the fair market value of the compensation received in the absence of evidence to the contrary." 30

In this and other uses of "fair market value" to determine the cash value of services, the term "fair market value" is not expressly defined. In contrast, in setting "fair market value" as the computational starting point for valuing fringe benefits, the IRS has defined "fair market value" to mean what "an individual would have to pay for the particular fringe benefit in an arm's-length transaction," without regard to "any special relationship" between employer and employee, or how the employee subjectively perceives the benefit's value, and not wholly determined by the benefit's cost to the employer. $^{31}$ This definition resembles the willing-buyer/willing-seller definition of the "fair market value" of property. Both refer to a hypothetical transaction in which the buyer and seller have no prior relationship ("arm's-length transaction"). Fringe benefits can be services, such as, for example, chauffeur services. ${ }^{32}$ This too implies no sharp difference in the meaning of "fair market value" when used to determine the cash value of services rather than property.

Given federal tax law's widespread use of "fair market value" to value services, judges and tax officials may be inclined to use "fair market value" to calculate the cash value of an unpaid worker's services. ${ }^{33}$ Importantly, "fair market value" does not necessarily require taking the contract price as the full measure of the service's cash value, though judges could well treat it as presumptively so. In this respect, "fair market value" operates no differently, better or worse, for valuing services than for valuing property in screening out those aspects of the actual transaction that may have led to a

${ }^{27} 22$ Fed. Reg. 9420 (Nov. 26, 1957) (II(B)). The 1938 antecedent to the current Treas. Reg. $\S 1.61-2(d)(1)$ referred only to payment for services with "something other than money" and the "fair market value" of the "thing" taken in payment," and presumed that, absent contrary evidence, any "stipulated price" for services rendered was the "fair value" of the compensation received. Treas. Reg. § 3.22(a)-3 (1938).

${ }^{28}$ Treas. Reg. $§ 1.61-2(d)(1)$.

${ }^{29}$ Rev. Rul. 79-24, 1979-1 C.B. 60. See also Badell v. Comm'r, 80 T.C.M. (CCH) 422, 425 (2000) (roofing services as income).

${ }^{30}$ Treas. Reg. $\S 1.61-2(\mathrm{~d})(1)$

${ }^{31}$ Treas. Reg. $\$ 1.61-21(\mathrm{~b})(1)-(2)$ (as amended in 1992).

${ }^{32}$ Treas. Reg. $\$ 1.61-21(\mathrm{~b})(5)$ (specifying how to compute fair market value of chauffeur services provided as fringe benefit).

${ }^{33}$ See, e.g., Koons v. United States, 315 F.2d 542, 545 (9th Cir. 1963) (upholding IRS use of "fair market value" to determine cash value of employer provision of moving company services to transport employee's household furniture); Rooney v. Comm'r, 88 T.C. 523, 528-29 (1987) (finding for federal income tax purposes the "fair market value" of goods and services received by accounting firm to cover unpaid bills to be the prices charged by the firm's clients to their retail customers, and citing the willing-buyer/willingseller definition of "fair market value" under federal estate tax, Treas. Reg. § 20.2031-1(b) (as amended in 1965)). 
higher or lower contract price. For example, we might suppose that the contract price for services exceeds "fair market value" where a restaurant owner's sister pressures the owner to hire his nephew as wait staff for wages higher than what that owner could have paid a stranger to do the same work.

More importantly, the "fair market value" concept also requires accounting for federal and state laws that affect the contract price for labor. Federal and state wage and hour statutes impose a price floor in labor markets, much as government price floors exist for certain commodities, such as cow's milk. ${ }^{34}$ Federal employment discrimination statutes prohibit wage discrimination with respect to certain worker characteristics. These laws matter, because "fair market value" seems to require imagining, as part of the hypothetical arm's-length transaction, that the hypothetical buyer and seller complete the transaction without violating the legislated price floor or wage-discrimination prohibitions.

For example, a sale price below a price floor set by a minimum wage statute seems to suggest that the seller was "under [a] compulsion" to sell at that price, because the "fair market value" concept requires imagining hypothetical sellers that aim to maximize sale price ${ }^{35}$ and that have "reasonable knowledge of the relevant facts," here the minimum sale price set by applicable wage and hour statutes. If so, the price floor set by minimum wage law determines the minimum cash value of services generated by the "fair market value" inquiry, precisely because at the time of the actual transaction, that price floor applied generally to all buyers and sellers of those services. To illustrate, suppose again that an employer promises $\$ 100$ in exchange for certain services, but pays only $\$ 45$. Before, we had assumed that $\$ 100$ was the cash value of those services, and from there concluded that the employer had gained $\$ 55$ in gross income. If, however, the applicable minimum wage statute had required the employer to pay at least $\$ 120$ at that time, then no matter what the employer actually promised to pay, the employer has gained at least $\$ 75$ in gross income.

Similarly, where the restaurant owner hires a woman as a waiter for wages lower than what that owner would have had to pay a man to do the same work, the contract price for those services falls below "fair market value," if that concept requires us to screen out any illegal labor market disadvantage that hypothetical female sellers of labor have because they are women. Thus, if the Equal Pay $\mathrm{Act}^{36}$ forbids paying the female waiter less than current male waiter employees to do the same work, then a contract price that falls below the male waiters' wages may fall below "fair market value," because "fair market value" assumes, again, that sellers aim to maximize sale price and have "reasonable knowledge of the relevant facts," here how much the male waiters receive in wages and that any contract price below that amount violates the Equal Pay Act.

This analysis is consistent with how "fair market value" is usually applied to property so as to account for statutes or regulations that restrict the use or sale of that

1996).

${ }^{34}$ For brief discussion, see Milk Indus. Found. v. Glickman, 949 F. Supp. 882, 885-88 (D.D.C.

${ }^{35}$ For "fair market value" of property, the Tax Court has sometimes expressed this intuition. See Dillard v. Comm'r, 20 T.C.M. (CCH) 137, 143 (1961) ("Fair market value contemplates two parties, both driving the hardest bargain he can to obtain the best possible price for himself."); see also Jonathan T. Bromwell \& Assoc. v. Comm'r, 66 T.C.M. (CCH) 799, 808 (1993) ("To determine that an arm's-length transaction took place, we must find that the buyer was motivated to secure the lowest purchase price possible and, conversely, that the seller looked to obtain the highest price.").

${ }^{36} 29$ U.S.C. § 206(d) (2006). 
property, such as zoning and environmental laws, or regulations on the sale of securities. ${ }^{37}$ The main difference may be that, putting aside wage ceilings, accounting for restrictions on the contract price for services-usually imposed on the buyer of services (the employer) - tends to increase the price of the services provided in the hypothetical arm's-length transaction. In contrast, accounting for restrictions on the sale of propertyusually imposed on the seller of property - may tend to reduce the price of the property in the hypothetical arm's-length transaction, effectively forcing one to calculate a discount for the restriction's effect on the marketability of the property.

To be sure, the IRS also uses "fair market value" to value illegal goods, such as relying on the "retail street price" of illicit drugs, ${ }^{38}$ which requires imagining the hypothetical buyer and seller violating the law by completing the transaction. The reason, however, is that although the very transaction is illegal at any price, without imagining it nonetheless, there would be no market at all from which to estimate cash value. The same reasoning would apply to using "fair market value" to determine the cash value of categorically illegal services, such as prostitution or private assassination. In contrast, price regulation of services, such as minimum wage statutes or the Equal Pay Act, imply a legal market for those services, because no legislature regulates prices for services that it has already banned at any price.

\section{B. Wage Underpayment and Business Expense Deductions}

The employer that practices wage underpayment may also face tax consequences for deducting unpaid wages, as well as certain kinds of wage payments, as business expenses. Under $\S 162(a)$ of the Code, a taxpayer may deduct "all the ordinary and necessary expenses paid or incurred during the taxable year in carrying on any trade or business, including ... a reasonable allowance for salaries or other compensation for personal services actually rendered." 39 Unless otherwise indicated, the timing of this deduction depends on the taxpayer's method of accounting. ${ }^{40}$

The wage-underpaying employer faces two tax consequences with respect to how it claims business expense deductions for its wage payments. First, whereas a cashmethod employer can never deduct unpaid wages as business expenses, an accrualmethod employer may do so under certain circumstances subject to operation of the tax benefit rule. Second, regardless of its accounting method, an employer cannot deduct paid wages as business expenses if such wage payments violate provisions of minimum wage statutes that impose criminal penalties.

\section{1. $\quad$ Unpaid Wages as Business Expense Deductions}

A business deduction for unpaid wages may be allowed, but this depends initially on the taxpayer's chosen method of tax accounting. Under the cash and disbursements method of accounting, wages are deductible as business expenses when paid. Therefore, since unpaid wages are not "paid" compensation expenses for already rendered services, a cash method employer cannot deduct unpaid wages as business expenses.

\footnotetext{
${ }^{37}$ See generally BOGDANSKI, supra note 23 , I[ 6.02 .

${ }^{38}$ See, e.g., Jones v. Comm'r, 61 T.C.M. (CCH) 1721, 1736 (1991) ("retail street value" of cocaine); Caffery v. Comm'r, 60 T.C.M. (CCH) 807, 816 (1990) (using "market value" and "street value" interchangeably to refer to cash value of marijuana).

${ }^{39}$ I.R.C. § 162(a)(1) (2006).

${ }^{40}$ I.R.C. $§ 461$ (a) (2006). For examples of different timing rules for deducting compensation to
} another for services rendered, see I.R.C. § 83(h) (2006) and I.R.C. § 404(a)(5) (2006). 
For the accrual method employer, however, business expense deductions are, in theory, allowable for unpaid wages under certain circumstances. An accrual method taxpayer can usually deduct business expenses that have been "incurred . . . in the taxable year in which all the events have occurred that establish the fact of the liability, the amount of the liability can be determined with reasonable accuracy, and economic performance has occurred with respect to the liability." ${ }^{41}$ If the taxpayer's liability arises because "another person" provides services to the taxpayer, as a worker provides services to an employer, then "economic performance occurs as such person provides such services." 42

Applying this test, suppose that in taxable year ${ }_{1}$, the accrual-method employer promises to pay the worker $\$ 100$, and the worker renders the services, but the employer only pays the worker $\$ 45$. Once all these events occur, that employer's liability to pay the worker the unpaid wages is established under state contract law. Alternatively, if under the applicable minimum wage the employer must pay $\$ 120$, but in fact the employer only pays $\$ 45$, the employer's liability to pay the worker $\$ 75$ is established under the minimum wage statute. In either case, the amount of the liability can be determined with reasonable accuracy, and economic performance has already occurred, because the worker has finished providing the promised services.

Two outcomes are possible. If, in our first example, that employer resolves to never pay the wages owed (\$55) in that same year $\left(\right.$ year $\left._{1}\right)$, then that $\$ 55$ cannot be an incurred compensation expense. Indeed, as discussed earlier, at that point, the employer gains an item of income if the services' cash value exceeds wages actually paid. This outcome is effectively the same as for the cash-method employer: In no year can this employer legally deduct the unpaid wages as business expenses.

Suppose, however, that the employer claims the $\$ 100$ (including the unpaid \$55) as a business expense deduction in year ${ }_{1}$, but resolves not to pay the $\$ 55$ in year $_{2}$. If so, then the deduction for that $\$ 55$ is allowable in year ${ }_{1}$, because in that year, the employer is still treating the unpaid wages as a debt to be paid. Once the employer stops treating the unpaid wages as a debt (in year ${ }_{2}$ ), the tax benefit rule applies. That rule provides that a taxpayer that took a deduction in a prior year must include that amount as income in a later year when an event in that later year is "fundamentally inconsistent with the premise on which the deduction was initially based."

Accordingly, in our example, the tax benefit rule triggers in year ${ }_{2}$, because in that year, the employer decided not to treat the unpaid $\$ 55$ as a debt owed to the worker. That decision is the event that is "fundamentally inconsistent" with the premise behind the deductibility of those unpaid wages in year ${ }_{1}$, that is, that the employer recognizes the $\$ 55$ in unpaid wages as a debt owed to the worker. ${ }^{44}$ However, if the employer would have

\footnotetext{
${ }^{41}$ Treas. Reg. § 1.461-1(a)(2) (as amended in 1998); see I.R.C. § 461(h)(4) (2006) ("For purposes of this subsection, the all events test is met with respect to any item if all events have occurred which determine the fact of liability and the amount of such liability can be determined with reasonable accuracy.").

${ }^{42}$ I.R.C. $\$$ 461(h)(2)(A)(i) (2206); accord Treas. Reg. $§ 1.461-1(d)(2)(i)$ (as amended in 1998).

${ }^{43}$ Hillsboro Nat'l Bank v. Comm'r, 460 U.S. 370, 383 (1983). The amount to be included as income in that later year, however, does not include the amount deducted if and "to the extent such amount did not reduce the amount of tax imposed" in the earlier year. I.R.C. § 111(a) (2006).

${ }^{44}$ Such an employer, however, cannot benefit from I.R.C. $\$ 1341$, which applies if and only if "an item was included in gross income for a prior taxable year (or years) because it appeared that the taxpayer had an unrestricted right to such item.” I.R.C. § 1341(a)(1) (2006). Courts and the IRS have refused to read this text to include cases in which the taxpayer obtained an item of income in a prior taxable year in a
} 
had the same tax liability regardless of whether it had deducted that $\$ 55$ in year $_{1}$, then the amount deducted in year ${ }_{1}$ is not treated as an item of income in year 2 .

\section{Wage Payments that Violate Criminal Provisions of Minimum} Wage Statutes Are Not Deductible

Regardless of accounting method, business expense deductions for already paid wages may be disallowed if such wage payments violate the Fair Labor Standards Act or (some) state minimum wage statutes. Section 162(c)(2) of the Code disallows business expense deductions "for any payment ... made, directly or indirectly, to any person, if the payment constitutes an ... illegal payment" under any federal law or "generally enforced" state law that, in pertinent part, "subjects the payor to a criminal penalty." 45 For example, when a corporation paid wages in violation of a wage ceiling, set by presidential executive order, that subjected to a criminal fine any person paying wages or salaries "higher than those permitted hereunder," then wages and salaries paid in excess of that wage ceiling counted as "illegal payments" under $\S 162(\mathrm{c})(2){ }^{46}$

For $\S 162(\mathrm{c})(2)$ to apply, however, the payment at issue must be in and of itself illegal, not just connected to or made to further illegal activity. ${ }^{47}$ To illustrate, although some have suggested otherwise, ${ }^{48}$ wages paid to undocumented workers are not clearly "illegal payments" under $\S 162(c)(2)$ just because federal immigration law imposes criminal penalties on employers that engage in a "pattern or practice" of violating certain statutory subsections concerning the employment of undocumented workers. ${ }^{49}$ Those subsections make it unlawful for any person to knowingly "hire, or to recruit or refer for a fee, for employment" an "unauthorized alien," or continue to employ the alien though knowing he or she is or has become an "unauthorized alien."

Although wage payments are certainly connected with these activities, ${ }^{51}$ these subsections do not clearly make the wage payments to undocumented workers illegal in and of themselves. For example, hiring an unauthorized alien under this statute occurs when the service or labor "commence[s]," because the word "hire" in the immigration statute means "the actual commencement of employment of an employee for wages or other remuneration," 52 and the word "employment" means "any service or labor performed by an employee for an employer within the United States." ${ }^{, 53}$ Thus, the wage

knowingly illegal way. See Kraft v. United States, 991 F.2d 292, 299 (6th Cir. 1993); McKinney v. United States, 574 F2d. 1240, 1243 (5th Cir. 1978); Perez v. United States, 553 F. Supp. 558, 561 (M.D. Fla. 1982); IRS Chief Counsel Advice 200808019 (Feb. 22, 2008) available at www.irs.gov/pub/irs-wd/0808019.pdf.

${ }^{45}$ I.R.C. $\$ 162(\mathrm{c})(2)(2006)$.

${ }^{46}$ Rev. Rul. 72-236, 1972-1 C.B. 41.

${ }^{47}$ Bilzerian v. United States, 41 Fed. Cl. 134, 138-40 (1998); Manning v. Comm'r, 97 T.C.M. (CCH) 1864, 1869 (2009); I.R.S. Field Serv. Advisory 200128004, 2001 WL 789909 (July 13, 2001).

${ }^{48}$ Katherine D. Black et al., Is the IRS the Solution to Illegal Immigration?, 35 WM. MITCHELL L. REV. 309, 330 (2008).

${ }^{49} 8$ U.S.C. $\$ 1324 \mathrm{a}(\mathrm{f})(1)(2006)$.

${ }^{50} 8$ U.S.C. $\S 1324 a(a)(1)(A),(a)(2)$.

${ }^{51}$ See, e.g., Incalza v. Fendi N. Am., Inc., 479 F.3d 1005, 1011 (9th Cir. 2007) (concluding that placing employee on unpaid leave after discovering his status as unauthorized alien complies with 8 U.S.C. $\S 1324 a(a)(2)$ by "in effect, suspend[ing]" the alien's employment status "during the period that he is neither working nor receiving pay").

52 8 C.F.R. § 274a.1(c) (2011). See Jenkins v. INS, 108 F.3d 195, 198 (9th Cir. 1997) (“If Santos had already begun physical labor, there can be little doubt that his employment had 'commenced' under 8 C.F.R. § 274a.1(c).”).

${ }^{5} 8$ C.F.R. § 274a.1(h). 
payments to undocumented workers are not illegal in and of themselves under that immigration statute, because the unauthorized alien can "commence[]" any particular service or labor before or after the employer pays wages to him or her for that service or labor.

In contrast, § 162(c)(2) does apply to wage payments made in violation of some minimum wage statutes. The Fair Labor Standards Act requires that "[e]very employer shall pay to each of his employees... wages" at certain specified rates. ${ }^{54}$ It further declares it "unlawful" for any person to violate that requirement and subjects any person who "willfully violates" that requirement to criminal penalties. ${ }^{55}$ Over half the states with minimum wage statutes similarly subject employers to criminal penalties for willfully paying below their state minimum wage rates.

Accordingly, if an employer pays a worker and, in so doing, violates these statutory provisions, then the payment in question is itself an "illegal payment" under $\S 162$ (c)(2) for which, as a result, no business expense deduction is allowed. To illustrate, suppose an employer willfully pays a worker $\$ 45$ in exchange for performing certain services, but that, under the FLSA, the employer is required to pay the worker at least $\$ 120$ for those services. If so, the employer violates the FLSA by paying the $\$ 45$ to the worker, and is subject to a criminal penalty for that violation. Accordingly, if the employer then takes the $\$ 45$ as a business-expense deduction under Code $\S 162$ (a), that deduction should be disallowed, because that $\$ 45$ is, in and of itself, an "illegal payment" under $\S 162(\mathrm{c})(2)$.

\section{No Payroll Tax or Withholding Liability}

This section concludes that it is unlikely that a court would find tax liability for wage underpayment under federal tax law governing payroll taxes and income withholding requirements.

\section{Payroll Taxes}

Since their inception, federal programs for old age and disability insurance (Social Security), Medicare, and state unemployment insurance have imposed payroll taxes on employers and employees. ${ }^{57}$ The Federal Insurance Contributions Act ("FICA") finances Social Security and Medicare by imposing on every individual a tax equal to a certain percentage of "the wages . . received by him with respect to employment," 58 as well as imposing "on every employer an excise tax, with respect to having individuals in his employ" equal to a certain percentage of "the wages ... paid by him with respect to employment."

\footnotetext{
${ }^{54} 29$ U.S.C. $\S 206(a)(1)$ (2006). See also 29 U.S.C. § 206(a)(2)-(4) (same for certain categories of workers)

${ }^{55}$ See 29 U.S.C. $\$ 216$ (a) (2006) (imposing a maximum fine of $\$ 10,000$, or imprisonment for up to six months, or both, for willfully violating 29 U.S.C. § 215); 29 U.S.C. § 215(a)(2) (2006) (declaring it unlawful to violate 29 U.S.C. § 206).

${ }^{56}$ See, e.g., MASs. GEN. Laws ch. 149 § 27C (2011); CAL. LAB. CodE § 1199 (2012); MD. CodE Ann., Lab. \& Empl. § 3-508 (West 2011). See generally Wage And Hour Laws: A STATe-By-STATE SuRVEY (Gregory K. McGillivary ed., 2004 \& Supp. 2010).

${ }^{57}$ On the decision to finance these programs with payroll taxes, see Mark H. Leff, Taxing the "Forgotten Man": The Politics of Social Security Finance in the New Deal, 70 J. Am. Hist. 359 (1983).

${ }^{58}$ I.R.C. § 3101(a)-(b) (2006).

${ }^{59}$ I.R.C. $\$ 3111$ (a)-(b) (2006).
} 
The Federal Unemployment Tax Act ("FUTA"), which governs unemployment insurance, contains similarly worded provisions: It imposes on employers "an excise tax, with respect to having individuals in his employ, equal to" a certain percentage "of the total wages ... paid by him . . . with respect to employment." 60

FICA also imposes a withholding requirement on employers: Employers must collect FICA taxes on employee wage income "by deducting the amount of the tax from the wages as and when paid." ${ }^{61}$ The employer has tax liability for these required deductions, ${ }^{62}$ as do third parties that pay wages to the employer's employees, ${ }^{63}$ even if the employee does not collect the wages "paid by" the employer. ${ }^{64}$

It is hard to read FICA and FUTA to impose tax obligations on owed but unpaid wages. FICA's statutory text refers to taxes on wages "received" by the employee and "paid" by the employer. FUTA's statutory text refers to wages "paid" by the employer. "Received" and "paid" are verbs used in the past tense. Unpaid wages are, by definition, wages that are not "received" and not "paid," or at least not yet. Although FICA and FUTA cover both actual and "constructive" wage payments, "constructive" wage payments occur only when the employer credits the wages to an employee's account, or sets them apart for the employee, so that "they may be drawn upon by him at any time although not then actually reduced to possession." 65

Similarly, FICA's employer withholding requirement also hinges on the employer's duty to deduct employee FICA tax from wages "as and when paid." Treasury regulations on FICA are more explicit: "The employer tax attaches at the time that the wages are paid by the employer," 66 and the "employee tax attaches at the time that the wages are received by the employee." 67 The phrase "at the time" in these regulations implies that the FICA employer and employee tax do not attach until the wages are paid and received, respectively.

\section{2. $\quad$ Income Tax Withholding}

Federal income tax withholding requirements do not authorize tax liability for failure to withhold taxes on wages owed but unpaid. Since the Current Tax Payment Act of $1943,{ }^{68}$ if an employer "mak[es] payment of wages," it must "deduct and withhold upon such wages a tax" determined by the Treasury Secretary. ${ }^{69}$ Although the statutory phrase "upon such wages" could be read to cover both wages paid and wages owed, a Treasury regulation conforms the employer's income-tax withholding obligation to the relevant text of the FICA withholding section: "The employer is required to collect the tax by deducting and withholding the amount thereof from the employee's wages as and

${ }^{60}$ I.R.C. $\S 3301$ (Supp. III 2009).

${ }^{61}$ I.R.C. $\$ 3102$ (a) (2006).

${ }^{62}$ I.R.C. $\$ 3102(\mathrm{~b})(2006)$.

${ }^{63}$ I.R.C. $\$ 3505$ (a) (2006).

64 Treas. Reg. $\$ 31.3102-1(d)$ (as amended in 2006).

65 Treas. Reg. $§ 31.3121$ (a)-2(b) (as amended in 2006) (FICA); Treas. Reg. § 31.3301-4 (1960) (same for FUTA).

${ }^{66}$ Treas. Reg. § 31.3111-3 (1960).

67 Treas. Reg. § 31.3101-3 (1960).

${ }^{68}$ For historical background, see Carolyn C. Jones, Class Tax To Mass Tax: The Role of Propaganda In The Expansion of the Income Tax During World War II, 37 BufF. L. Rev. 685 (1988).

${ }^{69}$ I.R.C. § 3402(a)(1) (2006). 
when paid, either actually or constructively."70 As with FICA and FUTA, employers make "constructive" wage payments for income-tax withholding purposes by crediting wages "to the account of or set apart for an employee so that they may be drawn upon by him at any time although not then actually reduced to possession."

The same conclusion applies to the backup-withholding requirement for nonwage payments for services, such as payments to independent contractors. Under this provision, if a "reportable payment" occurs, the payor may be required to deduct and withhold thirty-one percent of that payment if the payee failed to properly furnish the payor with an accurate tax identification number and the IRS informs the payor that the tax identification number is incorrect. ${ }^{72}$ The phrase "reportable payment" includes "any payment of a kind, and to a payee, required to be shown on a return required under" Code $\S 6041 \mathrm{~A}(\mathrm{a}){ }^{73}$ which in turn applies to "any service-recipient engaged in a trade or business" for payment of remuneration "in the course of such trade or business . . . to any person for services performed by such person," where "the aggregate of such remuneration paid to such person during such calendar year is $\$ 600$ or more."74

This withholding requirement triggers based only on actual payments of remuneration for services rendered, not just the obligation to pay such remuneration. The $\$ 600$ threshold is for "remuneration paid" to the person providing services. Treasury regulations confirm this reading: For backup withholding purposes, "[a]mounts are considered paid when they are credited to the account of, or made available to, the payee. Amounts are not considered paid solely because they are posted (e.g., an informational notation on the payee's passbook) if they are not actually credited to the payee's account or made available to the payee." 75

\section{THE METHODS OF INFORMING}

This Part identifies two ways for the unpaid worker to help enforce employer tax liability for wage underpayment: (1) becoming a tax informant, either gratis or for a reward; and (2) pursuing a qui tam tax fraud action against the employer under the (few) state false claims acts that would permit such claims. In these ways, the unpaid worker can transmit to the tax authority the information necessary to prove tax liability for wage underpayment. Such information includes not only the fact of underpayment, but also contract price, the type of services rendered, time actually worked, and other information relevant to determining the cash value of the services rendered. Absent such information from the unpaid worker, tax authorities will find it difficult to enforce employer tax liability arising from wage underpayment, because standard wage-reporting does not contain such information. $^{76}$

${ }^{70}$ Treas. Reg. § 31.3402(a)-1(b) (1983) (emphasis added). To be sure, employers may elect to adopt one among several methods of calculating how much tax to withhold based on the amount of wages estimated to be paid during a payroll period. I.R.C. § 3402(h) (2006). However, each of these calculation methods still depends on the initial input of the amount of wages paid by the employer. See, e.g., United States v. Fior D'Italia, 536 U.S. 238, 243 (2002) (upholding IRS's "aggregate" method of estimating employer FICA tax liability for tips as reasonable).

${ }^{71}$ Treas. Reg. § 31.3402(a)-1(b) (as amended in 1983).

${ }^{72}$ I.R.C. § 3406(a) (2006); Treas. Reg. § 31.3406(a)-1(a) (1995).

${ }^{73}$ See I.R.C. $\$ \$ 3406(\mathrm{~b})(1)(\mathrm{B}), 3406(\mathrm{~b})(3)(\mathrm{B})(2006)$.

${ }^{74}$ I.R.C. $\$ 6041 \mathrm{~A}(\mathrm{a})(2006)$

${ }^{75}$ Treas. Reg. § 31.3406(a)-4(a)(1) (as amended in 2002).

${ }^{76}$ Every year, employers must file a W-2 with the Social Security Administration for each worker. Every quarter, employers must file a Form 941 with the IRS and report, among other things, the number of 
A. Tax Informant

There are two main ways for the unpaid worker to become a tax informant. First, the unpaid worker can contact tax enforcement officials directly. For example, the IRS provides that any person who wishes to report possible instances of tax fraud by another individual, and does not want a reward, can complete and file a designated "information referral" form, or write a letter. ${ }^{77}$

Second, the unpaid worker can apply for a tax informant reward. Tax informant reward programs exist for federal taxes collected by the IRS, the Alcohol Tobacco Tax and Trade Bureau, ${ }^{78}$ and some state tax authorities (Table 1 ). In these programs, the reward is often some fraction of the tax recovered as a result of the information provided.

To illustrate, consider the IRS tax informant reward program. ${ }^{79}$ The IRS has the authority to pay sums "necessary" for "detecting underpayment of tax" or "detecting and bringing to trial and punishment persons guilty of violating the internal revenue laws or conniving at the same." 80 The IRS has discretion to pay an amount that would be "adequate compensation in the particular case, generally not to exceed fifteen percent of the amounts (other than interest) collected by reason of the information." 81 Since the reward is a percentage of amounts collected, the IRS acknowledges that rewards generally cannot be paid "for several years after the information is submitted, because the underlying taxpayer's case (including any appeals) must be resolved." 82

employees who received wages, tips, and other compensation during that quarter; the total amount of such compensation paid; and the total amounts withheld from such compensation for FICA and income tax. The Social Security Administration and the IRS work together to investigate discrepancies between an employer's Form 941 and W-2 wage reports. Social SECURITY AdMINISTRATION, Program OPERATIONS MANUAL SYSTEM RM 02070.001 (2001), available at https://secure.ssa.gov/apps10/poms.nsf/lnx/0102070001.

${ }^{77}$ Internal Revenue Manual 25.2.1.3 (Dec. 23, 2008), available at http://www.irs.gov/irm/part25/irm_25-002-001.html\#d0e66.

${ }^{78}$ This program's predecessor fell within the then-Bureau of Alcohol, Tobacco, and Firearms, 27 C.F.R. $\$ 70.41$ (2002), which had such authority at least since 1959, if not earlier, see Discovery of Liability and Enforcement of Title, 24 Fed. Reg. 8644 (Oct. 24, 1959) (set forth at Treas. Reg. § 301.7623-1(g)). Since its creation in 2003, however, no one has made use of the Alcohol Tobacco Tax and Trade Bureau's tax informant program. E-mail from Thomas K. Hogue, Director, Congressional and Public Affairs, Alcohol Tobacco Tax and Trade Bureau, to author (April 20, 2012) (on file with author).

${ }^{79}$ For descriptions, see Michelle M. Kwon, Whistling Dixie About the IRS Whistleblower Program Thanks to the IRC Confidentiality Restrictions, 29 VA. TAX REV. 447 (2010); Edward Morse, Whistleblowers and Tax Enforcement: Using Inside Information to Close the "Tax Gap", 24 AKRON TAX J. 1 (2009); Kneave Riggall, Should Tax Informants Be Paid? The Law and Economics of a Government Monopsony, 28 VA. TAX REV. 237 (2008); and Terri Gutierrez, IRS Informants Reward Program: Is It Fair?, 84 TAX NoTES TODAY 1203 (1999).

${ }^{80}$ I.R.C. $\$ 7623$ (a) (2006). Federal tax officials have had this authority since Act of Mar. 2, 1867, ch. $169, \S 7,14$ Stat. $471,473$.

${ }^{81}$ Treas. Reg. $\S 301.7623-1$ (c) (as amended in 2012).

${ }^{82}$ Internal Revenue Manual 25.2.1.1(5) (Dec. 23, 2008), available at http://www.irs.gov/irm/part25/irm_25-002-001.html\#d0e66. 
Table 1: Selected Tax Informant Reward Programs

\begin{tabular}{|c|c|c|c|}
\hline Agency & Tax Type & $\begin{array}{l}\text { Max\% Amounts } \\
\text { Collected As } \\
\text { Reward }\end{array}$ & Legal Authority \\
\hline $\begin{array}{l}\text { Internal Revenue } \\
\text { Service, U.S. Treasury } \\
\text { Dept. }\end{array}$ & All & $\begin{array}{l}\text { "generally"15\% } \\
\text { (except interest) }\end{array}$ & $\begin{array}{l}\text { I.R.C. § } 7623 \text { (2006); } \\
\text { Treas. Reg. § 301.7623-1 (as } \\
\text { amended in 2012) }\end{array}$ \\
\hline $\begin{array}{l}\text { Alcohol Tobacco Tax } \\
\& \text { Trade Bureau, U.S. } \\
\text { Treasury Dept. }\end{array}$ & $\begin{array}{l}\text { alcohol, } \\
\text { tobacco, } \\
\text { firearms }\end{array}$ & $10 \%$ & 27 C.F.R. $§ 70.41$ (2011) \\
\hline $\begin{array}{l}\text { California Board of } \\
\text { Equalization }\end{array}$ & sales, use & $10 \%$ & $\begin{array}{l}\text { CAL. REV. \& TAX. CODE } \S \\
7060 \text { (a) (2012) }\end{array}$ \\
\hline $\begin{array}{l}\text { California Franchise } \\
\text { Tax Board }\end{array}$ & $\begin{array}{l}\text { personal } \\
\text { income, } \\
\text { corporation }\end{array}$ & $10 \%$ & $\begin{array}{l}\text { CAL. REV. \& TAX. CODE } § 19525 \\
\text { (2012) }\end{array}$ \\
\hline $\begin{array}{l}\text { Oregon Dept. of } \\
\text { Revenue }\end{array}$ & Income & $\begin{array}{c}10 \% \text { of "net } \\
\text { amount of" tax, } \\
\text { penalties, interest }\end{array}$ & OR. REV. STAT. § 314.855 (2011) \\
\hline $\begin{array}{l}\text { Florida Dept. of } \\
\text { Revenue }\end{array}$ & All & $\begin{array}{c}10 \% \text { of tax, } \\
\text { penalties, interest }\end{array}$ & FLA. STAT. § 213.30 (2011) \\
\hline $\begin{array}{l}\text { Florida Dept. of } \\
\text { Business and } \\
\text { Professional } \\
\text { Regulation, Division of } \\
\text { Alcoholic Beverages \& } \\
\text { Tobacco }\end{array}$ & Cigarette & $\begin{array}{c}50 \% \text { of fine levied } \\
\text { and paid }\end{array}$ & FLA. STAT. § 210.18(11) (2011) \\
\hline $\begin{array}{l}\text { Florida Dept. of } \\
\text { Revenue }\end{array}$ & $\begin{array}{c}\text { vending } \\
\text { machine } \\
\text { items }\end{array}$ & $10 \%$ & $\begin{array}{l}\text { FLA. STAT. § 212.0515(3)(b) } \\
\text { (2011) }\end{array}$ \\
\hline $\begin{array}{l}\text { Kansas Dept. of } \\
\text { Revenue }\end{array}$ & $\begin{array}{l}\text { motor- } \\
\text { vehicle } \\
\text { fuels, } \\
\text { special } \\
\text { fuels }\end{array}$ & $10 \%$ & $\begin{array}{l}\text { KAN. STAT. ANN. § 79-3421 } \\
\text { (2011) }\end{array}$ \\
\hline
\end{tabular}


Figure 1: IRS Informant Program, FY1977-2010
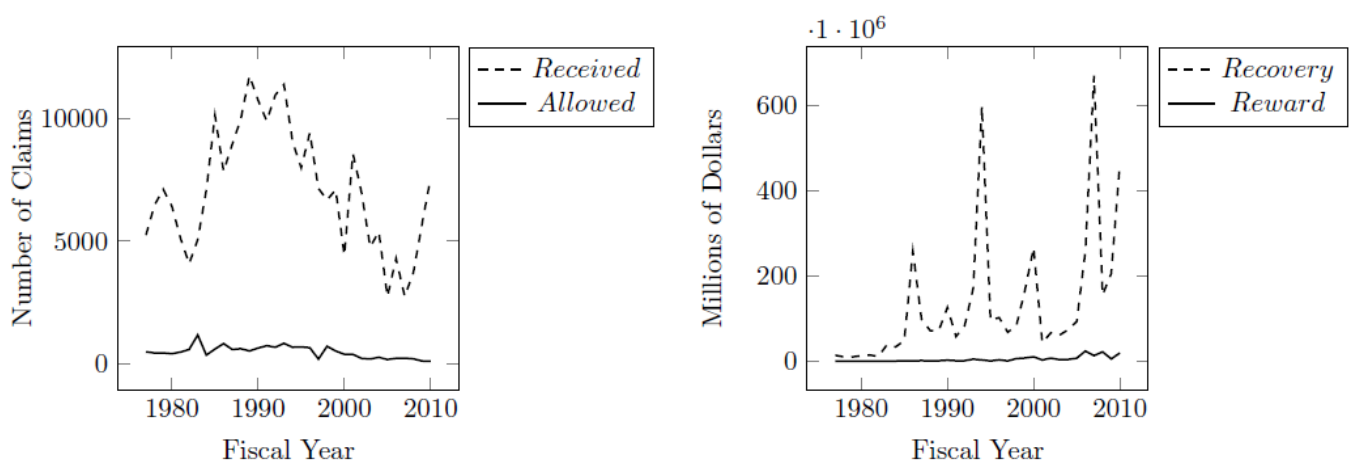

Figure 1 reports for fiscal years 1977-2010 the number of informant claims received and "allowed" by the IRS pursuant to I.R.C. $§ 7623(a)$, as well as the annual aggregate tax recovery (including penalties, fines, and interest) and informant rewards paid pursuant to that provision. ${ }^{83}$

In 2006, Congress enacted a more generous informant rewards program, codified at I.R.C. $§ 7623(\mathrm{~b})$. It entitles the informant to at least fifteen percent of any recovery if the IRS brings an administrative or judicial action based on the informant's information. However, for that provision to apply, the tax, penalties, interest, additions to tax, and additional amounts in dispute must exceed $\$ 2$ million. Any one unpaid-worker informant is unlikely to meet this threshold.

\section{B. Qui Tam Action under State False Claims Act}

Another option, available only in a few states, is a qui tam lawsuit under a false claims act. By January 2010, Congress, eighteen states, and the District of Columbia had enacted false claims acts ("FCAs") with qui tam provisions that apply to more than certain types of health fraud. ${ }^{84}$ However, Congress, eleven of these states, and the District of Columbia have expressly excluded claims under their FCAs based on any obligation under tax law. ${ }^{85}$ Moreover, the Florida legislature declared in 2002 that the state code section authorizing tax informant rewards is the "sole means" for seeking or obtaining money predicated upon another person's failure to comply with Florida tax law. ${ }^{86}$ Thus, a court is not likely to read Florida's FCA to authorize tax fraud claims.

${ }^{83}$ IRS provided the underlying data to the author for the fiscal years through 2007 . For fiscal years 2008-10, see IRS, FISCAL YEAR 2010 REPORT TO THE CONGRESS ON THE USE OF SECTION 7623 at tbl. 2 (2011),

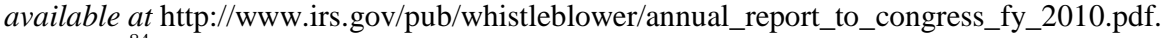

${ }^{84}$ JoHn T. BoEse, Civil FALSE Claims AND Qui TAM ACTIONS 6-3 (2010).

${ }^{85} 31$ U.S.C.A. $\$ 3729$ (d) (West Supp. 2011); CAL. Gov’T CODE $§ 12651$ (f) (West 2012); D.C. CODE § 2-381.02(d)(3) (2012); HaW. Rev. STAT. § 661-21(f) (2011); Mass. GEN. LaWS ch. 12, § 5B(12) (2011); Minn. Stat. § 15C.03 (2011); Mont. Code AnN. 17-8-403(4) (2011); N.C. Rev. Stat. § 1-607(c) (2011); N.J. Stat. AnN. 2A:32C-2 (2011); N.M. StAT § 44-9-3(E) (2011); OKLA. STAT. tit. 63 § 5053.1(E) (2011); Tenn. Code ANN. 4-18-103(f) (2011); VA. CodE ANN. § 8.01-216.3(D) (2011). For policy arguments favoring qui tam tax fraud actions, see Dennis J. Ventry Jr., Whistleblowers and Qui Tam for Tax, 61 TAX LAW. 357 (2008).

${ }^{86}$ Act of May 1, 2002, ch. 2002-218, § 37, 2002 Fla. Laws 1510, 1558 (codified at Fla. STAT. $\S 213.30(3)(2011)$ ). The provision was introduced as an amendment to Florida Senate Bill 426. See H. Amendment 042761, at 83 (filed March 14, 2002); S. 426E2, § 37, at 90-91, 2002 Leg., Reg. Sess. (Fla. 2002) (introduced March 23, 2002). Almost a year earlier, a Florida court had dismissed on procedural grounds a FCA qui tam tax fraud suit filed against West Palm Beach condominium owners. See Joe Kollin, 
The remaining six states have FCAs with provisions that can be read to cover tax claims ${ }^{87}$ but most of these impose substantial restrictions. Illinois and Indiana exclude claims under their FCAs based on their state income tax obligations. ${ }^{88}$ Rhode Island's FCA excludes claims based on its personal income tax, ${ }^{89}$ but it does not restrict claims based on its business income tax obligations. ${ }^{90}$ New York's FCA sets high defendant income and damage threshold for tax fraud claims. ${ }^{91}$ Although Nevada's FCA does not exclude tax obligations, Nevada has no state income tax. In contrast, Delaware, which taxes personal and corporate income, ${ }^{92}$ has an FCA that does not restrict tax fraud claims in any way.

\section{THE DECISION TO INFORM}

Even if courts and tax authorities agree that employers incur tax liability for wage underpayment as discussed above, only empirical research can show how much such liability would in fact deter employer wage underpayment or otherwise affect worker or employer behavior. To advance such research, this Part, drawing on the theoretical literature on the law enforcement uses of bounties and rewards, ${ }^{93}$ identifies major benefits and costs that might influence a worker to decide to inform the tax agency about the employer's wage underpayment (by the methods described above), assuming that the worker will do so if and only if the expected benefits exceeds its expected costs. An alternative exposition appears in the Appendix.

\section{A. Benefits}

Two important influences in favor of becoming a tax informant are the expected informant reward and any emotional satisfaction from facilitating tax recovery (e.g., revenge savored, conscience eased).

As noted in Table 1, most tax informant rewards are some fraction of the total tax recovery facilitated by the informant's assistance, often the tax owed plus penalties. In theory, the fact or amount of reward varies by enforcement mechanism. For simply sending a letter to the tax authority, of course, the expected money reward is zero. This implies that for those workers who actually pursue those avenues, the emotional satisfaction of facilitating recovery exceeds the expected costs of informing.

Moreover, in qui tam FCA actions, if we treat the probability of successful recovery as the probability that the qui tam plaintiffs will successfully recover the taxes and penalties owed in a court judgment, tax officials control the size of the expected informant bounty only by their decision to take control of the FCA lawsuit. For example,

Judge Tosses Suit on Unpaid Taxes, S. Fla. Sun-SEnTinel, April 4, 2001, at 1B; Joe Kollin, For-profit

Company Rebuffed in Lawsuit, S. FlA. Sun-SENTINEL, Jan. 22, 2001, at 1 B.

${ }^{87}$ Del. Code AnN. tit. $6 \S 1201$ (a)(7) (2011); 740 Ill. Comp. StAT. 175/3(a)(G) (2011); Ind. Code § 5-11-5.5-2(b)(6) (2011); NEv. Rev. STAT. § 357.040(1)(g) (2010); N.Y. STATE Fin. LAW § 189(1) (McKinney 2011); R.I. GEN. LAWS § 9-1.1-3(a)(7) (2011).

88740 Ill. COMP. STAT. 175/3(c) (2011); IND. CODE § 5-11-5.5-2(a) (2011).

${ }^{89}$ R.I. GEN. LAWS $§ 9-1.1-3(\mathrm{~d})(2011)$.

${ }^{90}$ R.I. GEN. LAwS. §§ 41-11-11(a)(1), 41-11-2(c) (2011) (relying on federal income tax definition as computational starting point).

${ }^{91}$ N.Y. STATE FIN. LAW $§ 189(4)(a)$ (2011) (defendant's net income or sales must be more than or equal to $\$ 1$ million for relevant taxable year, and pleaded damages must exceed \$350,000).

${ }^{92}$ See DEL. CoDE ANN. tit. 30, § 1105 (2011) (federal adjusted gross income as computational starting point for "entire taxable income" of a state resident); id. $§ 1903$ (corporation's federal taxable income as computational starting point for state corporation income tax).

${ }^{93} \mathrm{See}$, in particular, Yaniv, supra note 10. 
under the FCAs in Delaware and Rhode Island, if the state attorney general elects to proceed with a tax fraud action brought by the qui tam relator, that relator must be awarded no less than fifteen and no more than twenty-five percent of the proceeds of that action. If the state attorney general elects not to proceed, then the qui tam relator must be awarded no less than twenty-five percent and no more than thirty percent of the proceeds of the action. ${ }^{94}$

However, both the expected reward and any emotional satisfaction for facilitating recovery must be discounted by the probability that the tax authority will decide to audit the employer and successfully recover the taxes owed, plus penalties. This in turn consists of two separate variables: the odds of selecting the informant's employer for a tax audit, and, if audited, the odds of successfully recovering taxes owed from that employer. I discuss audit selection in Part IV(E) below.

\section{B. Costs}

There are three major kinds of costs to a worker who decides to inform the tax authorities about an employer's wage underpayment. First, the worker incurs a cost to search for and acquire the relevant information. This cost may presumably be low, because, as discussed above, the failure of the employer to pay the worker the wages promised is itself sufficient to make a credible case of employer tax liability. Second, the unpaid worker may suffer a psychic cost of informing, such as fear of reprisal, shame, or other forms of emotional discomfort. ${ }^{95}$

Search and psychic costs may vary, particularly when a labor union, law firm, or other NGO is involved. In some situations, such NGOs may actively support workers to become tax informants. In other situations, an NGO may be the tax informant by aggregating unpaid workers' information (e.g., by collecting worker affidavits) and applying to the tax authority for tax informant rewards on that basis. In either case, the unpaid worker must decide how much to cooperate with the NGO, but the NGO may reduce the worker's expected search and psychic costs by providing money, legal services, or emotional support arising from NGO esprit de corps.

The third cost item is the expected loss of future wages from the employer on whom the worker informs, discounted to present value. The size of this loss depends on if and when the employer fires the worker after identifying him or her as an informant. It also depends on how long the worker expects to continue to work for that employer after deciding to become an informant. And this in turn is partially determined by how competitive the relevant labor market is. In a competitive labor market, we should expect unpaid workers to immediately seek work elsewhere. As worker mobility costs increase, or as labor market competition becomes more imperfect, we should expect the unpaid worker to work longer for the underpaying employer, despite the apparent risk of future wage underpayment. The worker may prefer to accept some risk of future wage underpayment from that employer over a spell of unemployment.

Here, the amount of foregone future wages should vary by how the unpaid worker proceeds, in part because that affects the odds that the employer will identify the unpaid worker as the informant. For example, in qui tam FCA actions, if the unpaid worker is one of the named qui tam plaintiffs, then the employer can identify the worker-

${ }^{94}$ Del. Code AnN. tit. 6, § 1205(a),(b) (2011); R.I. GEN. LAws § 9-1.1-4(d)(1),(2) (2011).

${ }^{95}$ Qui tam FCA tax actions also entail court costs, litigation expenses, and attorney fees that may or may not be covered by a contingency-fee arrangement. To simplify, I have assumed that the cost of filing for tax informant status is zero. 
informant just by reading the complaint. For the tax informant who sends an informal letter or applies for a reward, the probability of employer identification will vary with how reliably the agency's procedures prevent disclosure of informant identity and how likely the procedure for imposing tax liability will cause disclosure of the informant's identity. ${ }^{96}$ To be sure, if the informant's emotional satisfaction in facilitating recovery comes from the employer knowing who helped tax officials detect the employer's tax violations, then that satisfaction will be higher if employer identification of the workerinformant is highly likely or certain.

Thus far, we have assumed that, once identified, the worker-informant will always be fired. However, even if the employer positively identifies the workerinformant, NGO support may reduce the risk of any subsequent firing. The employer may fear NGO economic pressure in response or a NGO-financed lawsuit under, for example, state whistleblower statutes or state tort law for wrongful discharge in violation of public policy. Such laws, however, vary by state and recovery under them is far from certain. ${ }^{97}$ To be sure, given such NGO support, unpaid workers may well pursue traditional legal remedies, such as an FLSA lawsuit, in any case.

\section{The Undocumented Worker}

We now consider the expected cost of deportation for a tax informant with undocumented immigration status. If the unpaid worker has undocumented immigration status, we should expect that worker, in deciding whether to become a tax informant, to be influenced by specific fears of deportation itself, and the costs of deportation discounted by the probability of deportation. For example, Gleeson (2010) found, from interviews with forty-one workers at "mainstream restaurant establishments" in San Jose, California, and Houston, Texas, that the thirty undocumented workers she interviewed tended not to complain about wage and hour violations or workplace safety concerns, because they feared deportation or other employer reprisals. ${ }^{98}$ Similarly, in her survey of Latino migrant laborers in New Orleans after Hurricane Katrina $(\mathrm{n}=194)$, Fussell (2011) found that over ninety percent were undocumented, and over forty percent reported experiencing wage nonpayment or underpayment - on average, two times during their time in New Orleans. In separate focus groups with twenty-five post-Katrina Latino migrants conducted in December 2009, participants explained that employers did threaten to call immigration authorities if the migrants complained, and that, because of the fear of deportation, the migrants accepted losses due to wage theft rather than complain. ${ }^{99}$

\footnotetext{
${ }^{96}$ For the IRS program, a tax informant's identity is not to be disclosed to any "unauthorized person.” Treas. Reg. § 301.7623-1(e) (as amended in 2012).

${ }^{97}$ For examples of court opinions rejecting state tort claims where the plaintiff alleged termination in retaliation for the plaintiff's reporting of employer violations of tax law, see Milton v. IIT Research Inst., 138 F.3d 519 (4th Cir. 1998); and Chism v. Mid-South Milling Co., 762 S.W.2d 552 (Tenn. 1988).

${ }^{98}$ Shannon Gleeson, Labor Rights for All? The Role of Undocumented Immigrant Status for Worker Claims Making, 35 LAW \& Soc. InQuiRy 561, 578, 581-86 (2010); see also Leisy J. Abrego, Legal Consciousness of Undocumented Latinos: Fear And Stigma as Barriers to Claims-Making for First- And 1.5Generation Immigrants, 45 LAW \& SoC'Y REV. 337, 365 (2011) ("Workers in this study [based on interviews with largely undocumented Salvadoran immigrants in Los Angeles] mentioned injuries, wage theft, and humiliation as part of their daily work environment, but, fearful of interacting with officials who may inquire about their legal status and possibly report them to [Immigration and Customs Enforcement] agents, few reported the abuse they suffered.").

${ }^{99}$ Elizabeth Fussell, The Deportation Threat Dynamic and Victimization of Latino Migrants: Wage Theft and Robbery, 52 SociologicAL Q. 593, 602-04, 607-08 (2011).
} 
Moreover, it is reasonable to assume that any change in the probability of employer identification of the tax informant will lead to a change in the same direction in the probability of informant deportation, for at least two reasons.

First, federal prosecutors and tax authorities lack the authority to bind federal immigration authorities to cooperation or immunity agreements for undocumented informants, absent their express written authorization from federal immigration authorities. ${ }^{100}$ There appears to be no existing interagency agreement between federal tax and immigration agencies concerning undocumented tax informants. Meanwhile, state officials have no authority to promise immunity from deportation or prosecution under federal law.

This may be a serious problem if the worker's decision to inform leads to a proceeding that authorizes discovery. Through discovery, an employer may come to learn of the informant's undocumented status. When undocumented workers are asked to provide testimonial evidence that pertains to immigration status, Cunningham-Parmeter (2008) argues that they could successfully invoke the Fifth Amendment privilege against self-incrimination, because of the quasi-criminal nature of removal proceedings. ${ }^{101}$ Moreover, courts can issue protective orders to preclude discovery that may reveal immigration status. ${ }^{102}$ However, seeking such an order may confirm third party suspicion of undocumented status. To date, no study has found how often motions for such protective orders succeed or how much such orders or the Fifth Amendment privilege reduce the risk of immigration status disclosure.

Second, it is uncertain how many, if any, undocumented workers will be eligible for U-1 non-immigrant status (a U-visa) for cooperating with law enforcement investigating tax violations. U-visa eligibility requires that (1) the applicant suffered "substantial physical or mental abuse as a result of having been a victim of criminal activity" that falls within particular statutory categories; (2) the applicant has information "concerning" that criminal activity; (3) the applicant has been, is being, or is likely to be helpful to federal, state, or local law enforcement in investigating or prosecuting that criminal activity; and (4) the criminal activity in question violated the laws of the United States or occurred in the United States. ${ }^{103}$

The statute, however, does not include tax fraud or theft-of-service among its categories of criminal activity. To be sure, it does include "perjury," a felony that a taxpayer commits by willfully misreporting income on a return. ${ }^{104}$ However, by regulation, a person who petitions for a U-1 visa as a "perjury" victim must show that he or she "has been directly and proximately harmed by the perpetrator" of the perjury, and that there are "reasonable grounds" to conclude that the perpetrator

10028 C.F.R. $§ 0.197$ (2011). For discussion, see, for example, Colleen Melody, Trading Information for Safety: Immigrant Informants, Federal Law-Enforcement Agents, and the Viability of NonDeportation Agreements, 83 WASH. L. REV. 599 (2008).

${ }^{101}$ Keith Cunningham-Parmeter, Fear of Discovery: Immigrant Workers and the Fifth Amendment, 41 CORNELl INT'L L. J. 27 (2008).

${ }^{102}$ FeD. R. Civ. P. 26(c); Rivera v. NIBCO, Inc., 364 F.3d 1057 (9th Cir. 2004). For examples of parallel authority in other courts, see TAX CT. R. 103(a) (2010); DEL. SUPER. CT. CIV. R. 26(c) (2012); R.I. R. CIV. P. 26(c) (2012).

1038 U.S.C. $\$ 1101(a)(15)(U)(i)(2006)$.

${ }^{104}$ See I.R.C. § 7206(1) (2006); Michael I. SALTZMAN, IRS PRACTICE AND Procedure II 7A.04(1)

(2009). 
committed the ... perjury offense, at least in principal part, as a means:

(1) To avoid or frustrate efforts to investigate, arrest, prosecute, or otherwise bring to justice the perpetrator for other criminal activity; or

(2) To further the perpetrator's abuse or exploitation of or undue control over the petitioner through manipulation of the legal system. ${ }^{105}$

To satisfy these additional requirements, a lawyer might argue that an employer committed tax perjury to help shield from official scrutiny the employer's capacity to wield the threat of deportation to exploit undocumented workers. On this reading, the threat of deportation is the requisite "manipulation of the legal system" used to further the employer's "exploitation or undue control over" the worker, and the fear of deportation is the "substantial . . . emotional abuse" suffered by the U-visa petitioner.

There is, however, little publicly available information from which to reliably estimate the odds that an agency or court would agree with this reading. Although a 2009 unpublished letter ruling can be read as concluding that fear of deportation cannot establish the requisite "substantial physical or mental abuse," 106 that ruling has not been designated "for publication as precedent in future proceedings." "107 Moreover, because not even the U.S. Citizenship and Immigration Service, which decides U-visa petitions, can currently track U-visa petitions by type of qualifying criminal activity alleged, ${ }^{108}$ we cannot easily ascertain the outcomes of past U-visa petitions, if any, that made such an argument. Of the over thirty letter rulings that the USCIS's Administrative Appeals Office issued to date since January 1, 2009 concerning the denial of a U-visa petition, none have concerned U-1 visas based on "perjury."109

D. Tax Informant Immunity?

We now consider a wage underpayment scenario in which the worker has also incurred tax liability of which the employer is aware, such as not reporting the wages he did receive as income. If wage underpayment occurs where the employer primarily conducts transactions in cash to avoid documentary evidence of taxable income or assets, unpaid workers may indirectly benefit insofar as such employers are less likely to report the wages they do pay, thereby making it easier for the worker not to report those wages as individual income. In this scenario, either worker or employer could decide to seek tax informant rewards by informing on the other to the tax authority.

This scenario resembles models in Cooter and Garoupa (2000) and Yadlin (2006) in which co-conspirators can defect or continue to cooperate under a regime where the defector's payoff is (1) a portion of the penalty that would be imposed on his coconspirator and (2) immunity to the extent of one's own gain from the conspiracy. Under certain assumptions, each co-conspirator faces a prisoner's dilemma such that, where the

1058 C.F.R. § 214.14(a)(14)(ii) (2011).

${ }^{106}$ Matter of [Redacted], No. EAC 08110 50406, 2009 WL 1742300 (Office of Admin. Appeals, Immigration and Naturalization Service Mar. 5, 2009); Farhang Heydari, Note, Making Strange Bedfellows: Enlisting the Cooperation of Undocumented Employees in the Enforcement of Employer Sanctions, 110 CoLuM. L. REV. 1526, 1554-57 (2010) (relying on this ruling).

1078 C.F.R. $\$ 103.3$ (c) (2011).

${ }^{108}$ E-mail from Chris Rhatigan, Public Affairs Officer, USCIS, to author (Dec. 2, 2010) (on file with author).

${ }^{109}$ Search of Westlaw database FIM-AAU ["section 101(a)(15)(u)"] on Jan. 4, 2012. 
payoffs for defecting are high enough and each can anticipate the other's payoffs, each is less likely to commit to cooperation in the first place. ${ }^{110}$

To illustrate, consider a one-shot prisoner's dilemma game between a worker and an employer who each face tax liability ( $\$ 50$ and $\$ 100$, respectively) and who can each inform on the other. Assume that tax liability is the same as the tax gain from cooperating and does not include penalties or interest. Assume also that any informant (worker or employer) gains immunity for tax liability he would have otherwise had, as well as a reward in the amount of a portion (15\%) of the other's tax liability, adjusted by the probability that the informant's information results in a successful tax recovery $(75 \%)$. If both worker and employer inform, then each has an equal chance of becoming the first to inform. Table 2 reports payoffs under these assumptions.

Table 2: One-Shot Worker-Employer Prisoner's Dilemma Game

\begin{tabular}{lcc}
\hline & Employer Cooperates & Employer Informs \\
\hline Worker Cooperates & $\$ 50, \$ 100$ & $\$ 12.50, \$ 105.63$ \\
\hline Worker Informs & $\$ 61.25, \$ 25$ & $\$ 30.63, \$ 52.82$ \\
\hline
\end{tabular}

If both worker and employer cooperate, the employer gains by avoiding tax liability for wage underpayment $(\$ 100)$ and the worker gains by avoiding tax liability for not reporting wages received (\$50). If only the worker informs, he gains $\$ 61.25: \$ 50$ from the tax immunity as well a reward of $\$ 11.25(=.75[.15(\$ 100)])$, while the employer loses the tax gain from wage underpayment, discounted by the probability of successful audit $(=.75(\$ 100))$. If only the employer informs, he gains $\$ 105.63: \$ 100$ from tax immunity as well as a reward of $\$ 5.63(=.75[.15(\$ 50)])$, while the worker only gets $\$ 12.50$, that is, $\$ 50$ as discounted by the probability of successful audit $(=.75(\$ 50))$. If both worker and employer inform, then we divide by half the payoffs in scenarios where the worker or the employer is the only informant (\$61.25/2 and $\$ 105.63 / 2$, respectively).

Under these conditions, both worker and employer will race to inform on the other. In turn, since they both will anticipate this result, both worker and employer are therefore less likely to underpay wages and fail to report paid wages as income, respectively. This result holds in part because we have assumed automatic tax immunity for informing. Indeed, in calculating payoffs, the tax immunity is more valuable than the expected informant reward. To date, however, tax officials appear unlikely to make a tax immunity guarantee part of an informant reward. To the contrary, current IRS policy provides that, for purposes of award computation under I.R.C. $§ 7623$, it is a "negative" factor that the informant "actively and knowingly participates in carrying out the tax noncompliance" or "directly or indirectly profits from the noncompliance."

\footnotetext{
${ }^{110}$ See Yadlin, supra note 10, at 31; Cooter \& Garoupa, supra note 10, at 5.

${ }^{111}$ Internal Revenue Manual 25.2.2.9.2(11)(B) (June 18, 2010) available at http://www.irs.gov/irm/part25/irm_25-002-002.html\#d0e844.
} 
Moreover, tax officials may be unwilling to forgo the discretion to grant or deny immunity or offer other reasons to cooperate, such as a sentencing recommendation, especially if the informant has more tax liability than the one on whom he informs. Absent an immunity guarantee, however, the unpaid worker may be less likely to decide to inform given uncertainty about how tax officials will react to the worker's own tax liability.

\section{E. Audit Selection}

This section discusses the difficulty of estimating the probability that the tax agency will select the employer to audit based on the unpaid worker's information and successfully recover the taxes owed plus penalties. We have thus far assumed that potential informants can accurately estimate this probability. ${ }^{112}$ This probability matters, because absent a tax authority audit of the employer, the tax authority cannot prove any employer tax liability as a result of its wage underpayment and, in turn, the worker is ineligible for any tax-informant reward.

An audit does not necessarily follow from a valid tax informant application. To reinforce the intuition, consider again Figure 1. It shows that, over a thirty-year period, the number of informant claims rewarded by the IRS has not varied to the same degree as the annual number of informant claims filed. This either implies that the fluctuations in informant claims consist primarily of annual changes in the number of meritless claims filed, or what is more likely, that the IRS audit budget sets a limit on the number of meritorious claims that the agency can pursue to recovery. This section considers two possible influences on audit selection among valid informant claims: expected net recovery and politics.

First, the audit selection literature assumes that audit selection is influenced in part by expected net recovery. In some models, ${ }^{113}$ a tax authority selects taxpayers to audit to maximize net tax revenue, but, absent an audit, the tax authority does not know whether any taxpayer's actual gross income is equal to or greater than their reported gross income. Under these conditions, the probability of selecting a particular taxpayer to audit is a function of the tax authority's estimate of the probability that there is income tax liability and the expected size of the net recovery from the audit (including penalties and interest, but subtracting the fixed cost of the audit).

A tax informant's information amounts to evidence that the taxpayer's gross income exceeds its reported gross income, and thus an audit is more likely if that information implies net tax owed. However, net tax recovery still may not be positive, because we must now also subtract the informant's reward from any audit recovery. Moreover, if the average net recovery is low for wage underpayment informant claims, the tax authority may elect to audit underpaying employers rarely. Wage-underpayment informants are effectively competing with other kinds of tax informants for a share of the tax authority's audit investment portfolio, and are, on this view, less attractive then potential audits with a higher expected return on investment.

To be sure, if the tax authority assumes that an employer who has underpaid the informant has more likely than not done so for all its workers, then the tax authority can estimate far higher gross tax recovery by multiplying it by the average number of workers

${ }^{112}$ Absent this assumption, we have to account for conditions under which potential informants are likely to overestimate or underestimate this probability, and thereby over- or underestimate their expected informant reward.

${ }^{113}$ See, e.g., James Andreoni et al., Tax Compliance, 36 J. ECON. LiTERATURE 818, 824-34 (1998). 
doing the same job for that employer in the taxable year. Another possibility is that, if wage underpayment occurs most often among small cash businesses, which are likely to underreport business cash income as well as evade employment tax and sales tax, ${ }^{114}$ then audits of underpaying employers may yield a far higher rate of return if tax auditors investigate more than the employer's wage-underpayment.

Second, in the research literature, there is some evidence of political influences on tax audit selection in general. Scholz and Wood (1998) found that, for the period 1974-1992, the odds of corporate versus individual IRS audits increased with greater Democratic party control over Congress, change in Presidents, and the composition of the taxpaying district and revenue, but not changes in state-level partisanship. ${ }^{115}$ Howard (2001) found that federal district court filings against the IRS were negatively correlated with a (lagged) ratio of the audits conducted during the period 1980-1988 of individuals with incomes over $\$ 70,000$ with audits of individuals with annual incomes under $\$ 70,000$. From this, he concluded that litigation led the IRS to shift audits away from the wealthy to the less affluent. ${ }^{116}$ Other studies have found effects on IRS audit behavior from the median ideology of the relevant federal court of appeals ${ }^{117}$ and the tax district's electoral importance to the President. ${ }^{118}$ If these findings hold with respect to tax audits of employers for wage underpayment, then it may well be that audits of underpaying employers, as identified by unpaid-worker informants, are more likely with more Democratic party control over Congress and for less affluent employers.

It will be difficult to measure how much expected net recovery and politics, among other possible influences, actually affect audit selection based on wageunderpayment informants. Tax informant claims files are likely the best data for this purpose, but confidentiality provisions typically restrict access to those files. Even with access, claims files may lack sufficient documentation. In an internal audit study of a non-random "judgmental sample" of IRS informant reward claim files processed in fiscal year 2005, the Treasury Inspector General for Tax Administration could not determine the justification for the percentage rewarded in thirty-two percent of the paid claims (seven out of twenty-two) and the rationale for rejection in seventy-six percent of rejected claims (fifty-two out of sixty-nine). ${ }^{119}$ The audit was based on a convenience sample, because at the time, the IRS had no nationwide informant claims database. ${ }^{120}$ Perhaps more recent informant claim files may better document the reasons for accepting or rejecting a claim if internal documentation protocols require an explicit accounting along

\footnotetext{
${ }^{114}$ See, e.g., Susan Cleary Morse et al., Cash Businesses and Tax Evasion, 20 STAN. L. \& POL'Y REV. 37, 39 (2009).

${ }^{115}$ John T. Scholz \& B. Dan Wood, Controlling the IRS: Principals, Principles, and Public Administration, 42 AM. J. PoL. SCI. 141, 160 (1998).

${ }^{116}$ Robert M. Howard, Wealth, Power, and the Internal Revenue Service: Changing IRS Audit Policy through Litigation, 82 Soc. ScI. Q. 268, 277 (2001).

${ }^{117}$ Robert M. Howard \& David C. Nixon, Regional Court Influence Over Bureaucratic Policymaking: Courts, Ideological Preferences, and the Internal Revenue Service, 55 POL. RES. Q. 907, 918 (2002).

${ }^{118}$ Marilyn Young et al., The Political Economy of the IRS, 13 ECON. \& POL. 201, 215 (2001).

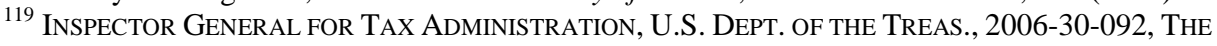
Informants' Rewards Program NeEds More Centralized Management Oversight 2 (2006).

${ }^{120} I d$. at $11 \mathrm{n} .2$.
} 
the enumerated positive and negative factors that now govern award computation for informant claims filed after July 2010. ${ }^{121}$

\section{COMPLEMENT TO OTHER LAW ENFORCEMENT APPROACHES}

This Part identifies two distinct advantages of the tax-liability approach to wage theft: (1) the tax authority's special collection powers; and (2) the non-deductibility of tax penalties as business expenses. These advantages warrant treating the tax-liability approach as a serious complement to other law enforcement approaches to combating wage theft.

First, tax authorities have a considerable advantage over the typical judgmentcreditor in collecting taxes owed. For example, if upon requisite notice a taxpayer neglects or refuses to pay taxes owed, the IRS can seize and sell that taxpayer's property or rights thereto. ${ }^{122}$ Moreover, if the taxpayer transfers its property to others to avoid collection, but still controls or benefits from that property, the IRS can sue the transferee directly in federal tax court, rather than pursue more cumbersome actions under state fraudulent conveyance statutes. ${ }^{123}$ To be sure, where the taxpayer has, at the outset, no assets to satisfy the judgment, these powers may not be useful. However, tax authorities do have an advantage over the typical judgment-creditor in combating efforts of the penalized employer to delay or defeat collection.

Second, the tax treatment of tax penalties is more favorable to preserving any deterrent effect of legal action, all else being equal, because tax penalties are not deductible as business expenses. Internal Revenue Code $\S 162$ (a) currently permits business-expense deductions for damages (compensatory and punitive), attorney's fees, and other costs that businesses pay to defend, settle, or satisfy judgments in lawsuits under various employment laws, including the FLSA. ${ }^{124}$ In this way, § 162(a) effectively provides business with a limited form of commercial liability insurance where policy limits increase with the applicable tax rate, and thus in theory dampens any deterrent effect that such lawsuits might have otherwise had on future employer behavior.

In contrast, tax penalties, as well as other civil and criminal penalties paid to a government, are not deductible as business expenses. Section 162(f) of the Code does not allow such deductions under $\S 162$ (a) "for any fine or similar penalty paid to a government for the violation of any law." 125 Fines aside, the word "similar" has been read to limit this section to cover civil penalties imposed to enforce the law and punish

${ }^{121}$ Internal Revenue Manual 25.2.2.9.2(3), (10)-(11) (June 18, 2010). available at http://www.irs.gov/irm/part25/irm_25-002-002.html\#d0e844.

${ }^{122}$ I.R.C. $§ 6331$ (2006).

${ }^{123}$ See I.R.C. § 6901(a)(1)(A)(i) (2006) (transferee liability for income tax liability). For an overview of transferee liability provisions in the Internal Revenue Code, see SALTZMAN, supra note 104, II 17.01.

${ }^{124}$ See Rev. Rul. 69-581, 1969-2 C.B. 25 (Fair Labor Standards Act liquidated damages payments and attorney fee award); Rev. Rul. 69-547, 1969-2 CB 24 (back pay and counsel fees awards under National Labor Relations Act); I.R.S. Priv. Ltr. Rul. 77-42-028 (July 20, 1977) (payments made under consent decrees or conciliation agreements to individuals by employers who were sued or charged with violating Title VII); William C. Atwater \& Co. v. Comm'r, 10 T.C. 218, 244-48 (1948) (judgment and legal costs of defending against former employee's civil action for breach of employment contract). Punitive damages may also be allowed as deductions under $\S 162$ (a). Rev. Rul. 80-211, 1980-2 C.B. 57, 58.

${ }^{125}$ I.R.C. $§ 162$ (f) (2006); see also Treas. Reg. § 1.162-21(a) (as amended in 1975). 
violators thereof, as opposed to civil penalties to encourage prompt compliance (e.g., penalties for late filing) or to compensate another for expenses caused by the violation. ${ }^{126}$

Moreover, the accompanying Treasury Regulation to $\S 162(\mathrm{f})$ provides that the phrase "fine or similar penalty" includes, among other things, an amount "[p]aid as a civil penalty imposed by Federal, State, or local law, including additions to tax and additional amounts and assessable penalties imposed by ... the Internal Revenue Code,"127 as well as an amount "[p]aid in settlement of the taxpayer's actual or potential liability for a fine or penalty (civil or criminal)." 128 The phrase "fine or similar penalty" does not include "legal fees and related expenses paid or incurred in the defense of a prosecution or civil action arising from a violation of the law imposing the fine or civil penalty, nor court costs assessed against the taxpayer, or stenographic and printing charges.",

The phrase "fine or similar penalty" also does not include "[c]ompensatory damages... paid to a government." 130 The latter gives rise to litigation over what portion, if any, of civil settlement payments to the government are properly characterized as a nondeductible "penalty" or as a potentially deductible "compensatory" payment. For example, according to the IRS, if a defendant in a FCA suit pays qui tam relator fees pursuant to a settlement of claims against it under the federal FCA, this payment does not count as a "penalty" under $\S 162(\mathrm{f})$. Rather, the relator-fees payment should be treated as an item of "compensatory damages ... paid" to the government to compensate the government for its existing legal obligation to pay those fees to the FCA relator. The offered reason is that, had the government paid the relator fees, it could have recovered those fees from the defendant under the FCA provision authorizing government recovery of its incurred enforcement costs. ${ }^{131}$

In contrast, where a taxpayer settles a claim for tax liability arising from wage underpayment, a tax informant's reward is a percentage of tax recovery (see Table 1). That tax recovery falls within the regulation that defines the phrase "fine or similar penalty" to include "additions to tax and additional amounts and assessable penalties imposed by ... the Internal Revenue Code." 132 Once a portion of that recovery is rewarded to the tax informant, there is arguably no basis to stop treating the amount of that reward as something other than a portion of a "penalty" under $\S 162(f)$.

This Part has identified two advantages of the tax-liability approach to combating wage theft: the tax authority's special collection powers and the non-deductibility of tax penalties as business expenses. The value of these advantages, however, must be discounted by the probability that the unpaid worker becomes a tax informant; that the tax authority audits that worker's employer on that basis; and that such audit generates enough proof to establish tax liability. For this reason, the tax-liability approach to wage theft only complements, not substitutes for, existing strategies for combating wage theft, such as private lawsuits and agency enforcement proceedings.

${ }^{126}$ See, e.g., S. Pac. Transp. Co. v. Comm'r, 75 T.C. 497, 650-52 (1980). For the interpretative genealogy of I.R.C. § 162(f), see F. Philip Manns, Jr., Internal Revenue Code Section 162(f): When Does the Payment of Damages to a Government Punish The Payor?, 13 VA. TAX Rev. 271, 276-288 (1993).

${ }_{127}$ Treas. Reg. $\$ 1.162-21$ (b)(1)(ii) (as amended in 1975).

${ }^{128}$ Treas. Reg. § 1.162-21(b)(1)(iii) (as amended in 1975).

${ }^{129}$ Treas. Reg. $\$ 1.162-21(\mathrm{~b})(2)$ (as amended in 1975).

${ }^{130} I d$.

${ }^{131}$ I.R.S. Chief Counsel Advice 2007-0015, at 5-9 (July 12, 2007) available at www.irs.gov/pub/irs-utl/am2007015.pdf.

132 Treas. Reg. § 1.162-21(b)(1)(ii). 


\section{CONCLUSION}

This paper has shown how, under existing federal and state tax law, underpaying employers face tax liability for failing to report unpaid wages as income or, in some circumstances, for claiming paid or unpaid wages as deductible business expenses. The paper then discussed the conditions under which unpaid workers might decide to help tax authorities enforce such liability by becoming tax informants or pursuing a qui tam tax fraud action. Finally, the paper identified two distinct advantages of pursuing tax liability as an important complement to other law enforcement approaches to wage theft.

The paper is limited in several respects. For example, it does not consider how such tax liability, if recognized, might affect the practices of unions, labor departments, lawyers and others who elect to pursue legal remedies on behalf of unpaid workers under, among other laws, state contract law, the Fair Labor Standards Act, or the Equal Pay Act. On the one hand, such tax liability may only negligibly affect case selection, given uncertainty as to whether the tax authority will select the case for audit and recovery, and given that underreporting gross income does not necessarily imply additional tax liability (and associated penalties). On the other hand, these actors may use employer fear of taxauthority audits on the basis of such tax liability to increase lawsuit settlement prices. I leave these and other implications of tax liability for wage underpayment for future research. 


\section{APPENDIX}

This appendix is an alternative to Part IV(A)-(C)'s discussion of the major gains and costs that might influence the worker deciding whether to inform the tax agency about the employer's wage underpayment.

Assume that the worker decides to inform the tax agency about the employer's tax evasion (by the methods described in Part III) if and only if the expected gain of such reporting (EG) exceeds its cost (C). Modifying Yaniv (2001), I model the decision to inform:

$$
E G \equiv \alpha[b(Z)+R]>s+k+\sum_{\mathrm{t}=0}^{\mathrm{n}}\left(1-\lambda_{t}\right) \delta_{t} w_{t}+\mathrm{U}\left[\theta(D)+k^{*}\right] \equiv \mathrm{C}
$$

where $\alpha$ is the probability that the tax agency will audit the employer and successfully recover all the taxes owed plus penalties; $Z$ is the amount of taxes and penalties owed; $R$ is the informant's emotional satisfaction for facilitating the recovery; $b$ is the fraction of the recovery to be rewarded to the informant; $s$ is the informant's cost of searching and acquiring the information; and $k$ is the psychic cost of informing. NGO support may reduce values of $k$ and increase values of $R$. For reporting to the tax authority without expectation of any reward, $b=0$, which implies that for workers who pursue this avenue, $R>C$

The term $\sum_{\mathrm{t}=0}^{\mathrm{n}}\left(1-\lambda_{t}\right) \delta_{t} w_{t}$ is the present value of expected future wages lost from the employer because of the decision to inform on that employer, where $\mathrm{w}=$ the wages to be received from the employer at the end of a time period $t$; the discount factor $\delta=1 /(1+r)^{t}$, where $r=$ a fixed discount rate; $\lambda=$ the probability that the employer will fire the worker for becoming an informant; and $n=$ the total number of time periods that worker expects to work for that employer after the worker's decision to inform, such that $n \leq$ the minimum value of $t$ for which $\lambda_{t}=1$. If the worker expects to leave the employer immediately after informing (e.g., to work elsewhere), then $n=0$. As we move from a perfectly competitive to a monopsonistic labor market, $n$ should increase. NGO support may decrease $\lambda$ if, because of such support, the employer is less likely to fire the worker even after identifying that worker as an informant.

The term $\mathrm{U}\left[\theta(D)+k^{*}\right]$ is the expected cost of deportation for undocumented immigration status, where $U=1$ if the worker has undocumented immigrant status, 0 if not; $\theta=$ the probability of deportation; $\mathrm{D}=$ the costs of deportation to the deported worker; and $\mathrm{k}^{*}=$ the specific fears of deportation. 